\title{
Cyclometalated Organoruthenium Complexes for Application in Dye-Sensitized Solar Cells
}

\author{
Sipke H. Wadman, ${ }^{\dagger}$ Jan M. Kroon,${ }^{\star}$ Klaas Bakker,${ }^{\star}$ Remco W. A. Havenith, ${ }^{\S}$ \\ Gerard P. M. van Klink, ${ }^{\dagger}, \#$ and Gerard van Koten*, ${ }^{*}$ \\ ${ }^{\dagger}$ Chemical Biology \& Organic Chemistry, and ${ }^{\S}$ Theoretical Chemistry, Debye Institute for Nanomaterials \\ Science, Faculty of Science, Utrecht University, Padualaan 8, 3584 CH Utrecht, The Netherlands, and \\ *ECN Solar Energy, PO Box 1, 1755 ZG Petten, The Netherlands. ${ }^{*}$ Present address: DelftChemTech, \\ Faculty of Applied Sciences, Delft University of Technology, Julianalaan 136, 2628 BL Delft,
} The Netherlands

Received June 7, 2009

\begin{abstract}
To investigate the viability of cyclometalation as a general tool in the design of new sensitizers for dyesensitized solar cells, a series of (cyclometalated) ruthenium complexes was prepared. To this purpose we have prepared the carboxylate-functionalized $2,2^{\prime}: 6^{\prime}, 2^{\prime \prime}$-terpyridine (tpy)-based tridentate ligands $4^{\prime}$-ethoxycarbonyl-2,2':6, $2^{\prime \prime}$-terpyridine $\left(\mathrm{EtO}_{2} \mathrm{C}-\mathrm{N}^{\wedge} \mathrm{N}^{\wedge} \mathrm{N}\right.$, 5), methyl-3,5-di(2-pyridyl)benzoate $\left(\mathrm{MeO}_{2^{-}}\right.$

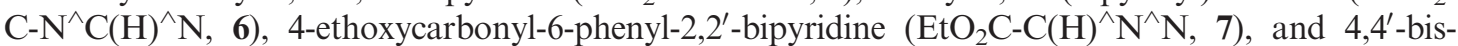
(methoxycarbonyl)-6-phenyl-2,2'-bipyridine $\left(\left(\mathrm{EtO}_{2} \mathrm{C}\right)_{2}-\mathrm{C}(\mathrm{H})^{\wedge} \mathrm{N}^{\wedge} \mathrm{N}, 8\right)$, and the ruthenium complexes thereof, $\left[\mathrm{Ru}\left(\mathrm{EtO}_{2} \mathrm{C}\right.\right.$-tpy)(tpy) $]\left(\mathrm{PF}_{6}\right)_{2}, \mathbf{1 a},\left[\mathrm{Ru}\left(\mathrm{MeO}_{2} \mathrm{C}-\mathrm{N}^{\wedge} \mathrm{C}^{\wedge} \mathrm{N}\right)(\mathrm{tpy})\right]\left(\mathrm{PF}_{6}\right), \mathbf{2 a},\left[\mathrm{Ru}\left(\mathrm{EtO}_{2} \mathrm{C}-\mathrm{C}^{\wedge} \mathrm{N}^{\wedge} \mathrm{N}\right)-\right.$ (tpy) $]\left(\mathrm{PF}_{6}\right), 3 \mathbf{a}$, and $\left[\mathrm{Ru}\left(\left(\mathrm{MeO}_{2} \mathrm{C}\right)_{2}-\mathrm{C}^{\wedge} \mathrm{N}^{\wedge} \mathrm{N}\right)(\right.$ tpy $\left.)\right]\left(\mathrm{PF}_{6}\right)_{2}$, 4a. In this series, cyclometalation results in a red shift as well as in a broadening of the electronic absorption features and is accompanied by a cathodic shift in the $\mathrm{Ru}^{\mathrm{II}} / \mathrm{Ru}^{\mathrm{III}}$ redox process. The complexes are photostable in both the $\mathrm{Ru}(\mathrm{II})$ and the $\mathrm{Ru}(\mathrm{III})$ state. Deprotection of the esters and grafting onto $\mathrm{TiO}_{2}$ resulted in a small additional red shift of the absorption features. Incorporation of the free acids of the complexes into a standardized solar cell shows efficient sensitization for the complexes $\mathbf{3 b}$ and $\mathbf{4} \mathbf{b}$, with the $\mathrm{C}, \mathrm{N}, \mathrm{N}^{\prime}$-bonding motif. The dicarboxylated complex $\mathbf{4 b}$ showed short circuit currents similar to those obtained for the benchmark compound N719. In contrast, for the free acid of $\mathbf{1 a}$, with the $\mathrm{N}, \mathrm{N}^{\prime}, \mathrm{N}^{\prime \prime}$-bonding motif, and for $\mathbf{2 a}$, with the $\mathrm{N}, \mathrm{C}, \mathrm{N}^{\prime}$-bonding motif, low efficiencies were observed. To put these results into perspective, we have applied TD-DFT calculations. The optical assignments based on these calculations correlated well with the spectral changes observed during $\mathrm{p} K_{\mathrm{a}}$ determinations. The complexes with the $\mathrm{C}, \mathrm{N}, \mathrm{N}^{\prime}$-bonding motif possess an excited state associated with the cyclometalated ligand, allowing efficient charge injection, while the complex with the $\mathrm{N}, \mathrm{C}, \mathrm{N}^{\prime}$-bonding motif possesses a more isolated excited state located on the remote tpy ligand and, as a result, is not capable of efficient charge injection into the $\mathrm{TiO}_{2}$ conduction band. This shows that the covalent carbon-to-ruthenium bond can be utilized as a tool to shift the operational threshold of the individual sensitizer for dye-sensitized solar cells toward lower energy, as long as care is taken that the nature of the excited state is appropriate for electron injection.
\end{abstract}

\section{Introduction}

In order to satisfy its rapidly growing energy demand, the world is still largely dependent on fossil fuels. ${ }^{1,2}$ A great amount of research has currently been focused on finding alternative energy sources, among which solar energy has increasingly become important. Already in $1991,{ }^{3}$ Grätzel and co-workers showed that by sensitizing large-bandgap semiconductors, cheap and efficient solar cells can be obtained,

*Corresponding author. E-mail: g.vankoten@uu.nl.

(1) Armaroli, N.; Balzani, V. The future of energy supply: Challenges and opportunities. Angew. Chem., Int. Ed. 2007, 46 (1-2), 52-66.

(2) Green, M. A. Recent developments in photovoltaics. Sol. Energy 2004, $76(1-3), 3-8$.

(3) O'Regan, B.; Grätzel, M. A low-cost, high-efficiency solar-cell based on dye-sensitized colloidal $\mathrm{TiO}_{2}$ films. Nature 1991, 353 (6346), $737-740$ now reaching energy power conversion efficiencies ( $\left.\eta_{\text {sun }}\right)$ up to $11 \%{ }^{4,5}$ In these systems, the need for expensive, high-purity materials has been eliminated by physically sequestering the charge separation process from the charge transport, performed by the dye material and a semiconductor, respectively. ${ }^{6}$ As light absorption and charge separation is performed by a single dye molecule, this system allows studying these processes

(4) Chiba, Y.; Islam, A.; Watanabe, Y.; Komiya, R.; Koide, N.; Han, L. Y. Dye-sensitized solar cells with conversion efficiency of $11.1 \%$. Jpn. J. Appl. Phys. Part 2 2006, 45 (24-28), 638-640.

(5) Nazeeruddin, M. K.; De Angelis, F.; Fantacci, S.; Selloni, A.; Viscardi, G.; Liska, P.; Ito, S.; Takeru, B.; Grätzel, M. G. Combined experimental and DFT-TDDFT computational study of photoelectrochemical cell ruthenium sensitizers. J. Am. Chem. Soc. 2005, 127 (48), 16835-16847.

(6) Kalyanasundaram, K.; Grätzel, M. Applications of functionalized transition metal complexes in photonic and optoelectronic devices. Coord. Chem. Rev. 1998, 177, 347-414. 
at the molecular level. The electrochemical and photophysical properties of the dye are crucial to the long-term stability ${ }^{7}$ and the light-harvesting efficiency of the solar cell. Next to stability issues, extinction coefficient, and injection efficiency, the overlap of the absorption spectrum of the dye with the solar spectrum is crucial. The ideal sensitizer for a single-junction photovoltaic cell converting AM 1.5 sunlight to electricity should absorb all light below a threshold of about $900 \mathrm{~nm} \cdot{ }^{8-10}$ Coordination complexes of ruthenium and osmium have shown the greatest potential as photosensitizers, ${ }^{10-18}$ the most well-known being the N719 dye $\left[\mathrm{Ru}(\mathrm{NCS})_{2}(\mathrm{dcbpy})_{2}\right]\left(\right.$ dcbpy $=4,4^{\prime}$-dicarboxy-

(7) Toyoda, T.; Sano, T.; Nakajima, J.; Doi, S.; Fukumoto, S.; Ito, A.; Tohyama, T.; Yoshida, M.; Kanagawa, T.; Motohiro, T.; Shiga, T.; Higuchi, K.; Tanaka, H.; Takeda, Y.; Fukano, T.; Katoh, N.; Takeichi, A.; Takechi, K.; Shiozawa, M. Outdoor performance of large scale DSC modules. J. Photochem. Photobiol., A 2004, 164 (1-3), 203-207.

(8) Grätzel, M. Conversion of sunlight to electric power by nanocrystalline dye-sensitized solar cells. J. Photochem. Photobiol., A 2004, $164(1-3), 3-14$

(9) Durr, M.; Bamedi, A.; Yasuda, A.; Nelles, G. Tandem dyesensitized solar cell for improved power conversion efficiencies. Appl. Phys. Lett. 2004, 84 (17), 3397-3399.

(10) Nazeeruddin, M. K.; Pechy, P.; Renouard, T.; Zakeeruddin, S. M.; Humphry-Baker, R.; Comte, P.; Liska, P.; Cevey, L.; Costa, E.; Shklover, V.; Spiccia, L.; Deacon, G. B.; Bignozzi, C. A.; Grätzel, M. Engineering of efficient panchromatic sensitizers for nanocrystalline $\mathrm{TiO}_{2}$-based solar cells. J. Am. Chem. Soc. 2001, 123 (8), 1613-1624.

(11) Altobello, S.; Argazzi, R.; Caramori, S.; Contado, C.; Da Fre, S.; Rubino, P.; Chone, C.; Larramona, G.; Bignozzi, C. A. Sensitization of nanocrystalline $\mathrm{TiO}_{2}$ with black absorbers based on Os and Ru polypyridine complexes. J. Am. Chem. Soc. 2005, 127 (44), 15342-15343.

(12) Nazeeruddin, M. K.; Kay, A.; Rodicio, I.; Humphry-Baker, R.; Mueller, E.; Liska, P.; Vlachopoulos, N.; Grätzel, M. Conversion of light to electricity by cis-X2bis(2,2'-bipyridyl-4, $4^{\prime}$-dicarboxylate)ruthenium(II) charge-transfer sensitizers ( $\mathrm{X}=\mathrm{Cl}-, \mathrm{Br}-, \mathrm{I}-, \mathrm{CN}-$, and $\mathrm{SCN}-$ ) on nanocrystalline titanium dioxide electrodes. J. Am. Chem. Soc. 1993, 115 (14), 6382-90.

(13) Nazeeruddin, M. K.; Pechy, P.; Grätzel, M. Efficient panchromatic sensitization of nanocrystalline $\mathrm{TiO}_{2}$ films by a black dye based on a trithiocyanato-ruthenium complex. Chem. Commun. (Cambridge) 1997, $18,1705-1706$.

(14) Chen, C. Y.; Wu, S. J.; Wu, C. G.; Chen, J. G.; Ho, K. C. A ruthenium complex with superhigh light-harvesting capacity for dyesensitized solar cells. Angew. Chem., Int. Ed. 2006, 45 (35), 5822-5825.

(15) Islam, A.; Sugihara, H.; Arakawa, H. Molecular design of ruthenium(II) polypyridyl photosensitizers for efficient nanocrystalline $\mathrm{TiO}_{2}$ solar cells. J. Photochem. Photobiol. A 2003, 158 (2-3), 131-138.

(16) Figgemeier, E.; Aranyos, V.; Constable, E. C.; Handel, R. W.; Housecroft, C. E.; Risinger, C.; Hagfeldt, A.; Mukhtar, E. Modification of electron transfer properties in photoelectrochemical solar cells by substituting $\{\mathrm{Ru}(\mathrm{terpy})(2)\}(2+)$ dyes with thiophene. Inorg. Chem. Commun. 2004, 7 (1), 117-121.

(17) Kroeze, J. E.; Hirata, N.; Koops, S.; Nazeeruddin, M. K.; Schmidt-Mende, L.; Grätzel, M.; Durrant, J. R. Alkyl chain barriers for kinetic optimization in dye-sensitized solar cells. J. Am. Chem. Soc. 2006, $128(50), 16376-16383$.

(18) Wang, P.; Klein, C.; Humphry-Baker, R.; Zakeeruddin, S. M.; Gratzel, M. A high molar extinction coefficient sensitizer for stable dyesensitized solar cells. J. Am. Chem. Soc. 2005, 127 (3), 808-809.

(19) Ferrere, S.; Gregg, B. A. Photosensitization of $\mathrm{TiO}_{2}$ by [Fe-II$\left(2,2^{\prime}\right.$-bipyridine-4, $4^{\prime}$-dicarboxylic acid $\left.)(2)(\mathrm{CN})(2)\right]$ : Band selective electron injection from ultra-short-lived excited states. J. Am. Chem. Soc. 1998, 120 (4), 843-844.

(20) Geary, E. A. M.; Hirata, N.; Clifford, J.; Durrant, J. R.; Parsons, S.; Dawson, A.; Yellowlees, L. J.; Robertson, N. Synthesis, structure and properties of $\left[\mathrm{Pt}\left(2,2^{\prime}\right.\right.$-bipyridyl-5,5'-dicarboxylic acid)(3,4-toluenedithiolate)]: tuning molecular properties for application in dye-sensitised solar cells. Dalton Trans. 2003, 19, 3757-3762.

(21) Geary, E. A. M.; Yellowlees, L. J.; Jack, L. A.; Oswald, I. D. H.; Parsons, S.; Hirata, N.; Durrant, J. R.; Robertson, N. Synthesis, structure, and properties of $\left[\mathrm{Pt}(\mathrm{II})\right.$ (diimine)(dithiolate)] dyes with $3,3^{\prime}-$, 4,4'-, and 5,5'-disubstituted bipyridyl: Applications in dye-sensitized solar cells. Inorg. Chem. 2005, 44 (2), 242-250.

(22) Mayo, E. I.; Kilsa, K.; Tirrell, T.; Djurovich, P. I.; Tamayo, A.; Thompson, M. E.; Lewis, N. S.; Gray, H. B. Cyclometalated iridium(III)-sensitized titanium dioxide solar cells. Photochem. Photobiol. Sci. 2006, 5 (10), 871-873. $2,2^{\prime}$-bipyridine $)^{12}$ and the black dye $\left[\mathrm{Ru}(\mathrm{NCS})_{3}(\right.$ tctpy) $]($ tctpy $=$ $4,4^{\prime}, 4^{\prime \prime}$-tricarboxy-2, $2^{\prime}: 6^{\prime}, 2^{\prime \prime}$-terpyridine). ${ }^{10}$ Polypyridine complexes of other transition metals such as iron, ${ }^{19}$ platinum, ${ }^{20,21}$ iridium, ${ }^{22}$ and rhenium ${ }^{23,24}$ have also yielded promising results, as have conjugated organic compounds, ${ }^{25-32}$ porphyrins, ${ }^{33-35}$ and quantum dots. ${ }^{36-38}$ Apart from the long-term stability, one of the major aims in this research field is to improve the red response of the dye-sensitized solar cell toward the theoretical operational threshold around $900 \mathrm{~nm}$. Since visible absorptions in polypyridine complexes of ruthenium are metal-toligand charge transfer (MLCT) based, ${ }^{39}$ one can red-shift the

(23) Asbury, J. B.; Hao, E. C.; Wang, Y. Q.; Lian, T. Q. Bridge length-dependent ultrafast electron transfer from Re polypyridyl complexes to nanocrystalline $\mathrm{TiO}_{2}$ thin films studied by femtosecond infrared spectroscopy. J. Phys. Chem. B 2000, 104 (50), 11957-11964.

(24) Wang, Y. Q.; Asbury, J. B.; Lian, T. Q. Ultrafast excited-state dynamics of $\operatorname{Re}(\mathrm{CO})(3) \mathrm{Cl}(\mathrm{dcbpy})$ in solution and on nanocrystalline $\mathrm{TiO}_{2}$ and $\mathrm{ZrO}_{2}$ thin films. J. Phys. Chem. A 2000, 104 (18), 4291-4299.

(25) Kim, S.; Lee, J. K.; Kang, S. O.; Ko, J.; Yum, J. H.; Fantacci, S.; De Angelis, F.; Di Censo, D.; Nazeeruddin, M. K.; Grätzel, M. Molecular engineering of organic sensitizers for solar cell applications. J. Am. Chem. Soc. 2006, 128 (51), 16701-16707.

(26) Horiuchi, T.; Miura, H.; Sumioka, K.; Uchida, S. High efficiency of dye-sensitized solar cells based on metal-free indoline dyes. J. Am. Chem. Soc. 2004, 126 (39), 12218-12219.

(27) Hara, K.; Sayama, K.; Arakawa, H.; Ohga, Y.; Shinpo, A.; Suga, $\mathrm{S}$. A coumarin-derivative dye sensitized nanocrystalline $\mathrm{TiO}_{2}$ solar cell having a high solar-energy conversion efficiency up to $5.6 \%$. Chem. Commun. (Cambridge, U.K.) 2001, 6, 569-570.

(28) Kaletas, B. K.; Kozhevnikov, V. N.; Zimine, M.; Williams, R. M.; Konig, B.; De Cola, L. Sensitization of nanocrystalline $\mathrm{TiO}_{2}$ films with carboxy-functionalized bis(indolyl)maleimide. Eur. J. Org. Chem. 2005, 16, 3443-3449.

(29) Morandeira, A.; Fortage, J.; Edvinsson, T.; Le Pleux, L.; Blart, E.; Boschloo, G.; Hagfeldt, A.; Hanmiarstrom, L.; Dobel, F. Improved photon-to-current conversion efficiency with a nanoporous p-type $\mathrm{NiO}$ electrode by the use of a sensitizer-acceptor dyad. J. Phys. Chem. C 2008, 112 (5), 1721-1728.

(30) Hagberg, D. P.; Marinado, T.; Karlsson, K. M.; Nonomura, K.; Qin, P.; Boschloo, G.; Brinck, T.; Hagfeldt, A.; Sun, L. Tuning the HOMO and LUMO energy levels of organic chromophores for dye sensitized solar cells. J. Org. Chem. 2007, 72 (25), 9550-9556.

(31) Hara, K.; Sato, T.; Katoh, R.; Furube, A.; Ohga, Y.; Shinpo, A.; Suga, S.; Sayama, K.; Sugihara, H.; Arakawa, H. Molecular design of coumarin dyes for efficient dye-sensitized solar cells. J. Phys. Chem. B 2003, 107 (2), 597-606.

(32) Qin, P.; Yang, X. C.; Chen, R. K.; Sun, L. C.; Marinado, T.; Edvinsson, T.; Boschloo, G.; Hagfeldt, A. Influence of pi-conjugation units in organic dyes for dye-sensitized solar cells. J. Phys. Chem. C 2007, 111 (4), 1853-1860

(33) Reddy, P. Y.; Giribabu, L.; Lyness, C.; Snaith, H. J.; Vijaykumar, C.; Chandrasekharam, M.; Lakshmikantam, M.; Yum, J. H.; Kalyanasundaram, K.; Grätzel, M.; Nazeeruddin, M. K. Efficient Sensitization of nanocrystalline $\mathrm{TiO}_{2}$ films by a near-IR-absorbing unsymmetrical zinc phthalocyanine. Angew. Chem., Int. Ed. 2007, 46 (3), 373-376.

(34) Huijser, A.; Suijkerbuijk, B. M. J. M.; Klein Gebbink, R. J. M.; Savenije, T. J.; Siebbeles, L. D. A. Efficient exciton transport in layers of self-assembled porphyrin derivatives. J. Am. Chem. Soc. 2008, 130 (8), $2485-2492$.

(35) Robertson, N. Catching the rainbow: Light harvesting in dyesensitized solar cells. Angew. Chem., Int. Ed. 2008, 47 (6), 1012-1014.

(36) Plass, R.; Pelet, S.; Krueger, J.; Grätzel, M.; Bach, U. Quantum dot sensitization of organic-inorganic hybrid solar cells. J. Phys. Chem. B 2002, 106 (31), 7578-7580.

(37) Shen, Q.; Yanai, M.; Katayama, K.; Sawada, T.; Toyoda, T. Optical absorption, photosensitization, and ultrafast carrier dynamic investigations of CdSe quantum dots grafted onto nanostructured $\mathrm{SnO}_{2}$ electrode and fluorine-doped tin oxide (FTO) glass. Chem. Phys. Lett. 2007, 442 (1-3), 89-96.

(38) Shen, Q.; Arae, D.; Toyoda, T. Photosensitization of nanostructured $\mathrm{TiO}_{2}$ with $\mathrm{CdSe}$ quantum dots: effects of microstructure and electron transport in $\mathrm{TiO}_{2}$ substrates. J. Photochem. Photobiol. A 2004, 164 (1-3), 75-80.

(39) Juris, A.; Balzani, V.; Barigelletti, F.; Campagna, S.; Belser, P.; Von Zelewsky, A. Ruthenium(II) polypyridine complexes: photophysics, photochemistry, electrochemistry, and chemiluminescence. Coord. Chem. Rev. 1988, 84, 85-277. 
absorption properties by either lowering the energy of the ligand-based acceptor states or destabilizing the metal-based levels. The former strategy has been widely applied to obtain compounds that have both a red-shifted absorption and an increased extinction coefficient. ${ }^{10,40-44}$ Increasing the electron density at the ruthenium center, thereby cathodically shifting the complex's oxidation potential, also results in red-shifted absorption features. Although less common, this second strategy has also been applied to optimize the sensitizer. ${ }^{45-48}$

Cyclometalation is a tool that strongly affects the redox potentials of complexes compared to their non-cyclometalated congeners. Isoelectronic replacement of a neutral donor heteroatom by an anionic carbon center in a multidentate ligand containing additional donor heteroatoms significantly changes its electronic properties. ${ }^{49-54}$ Moreover, cyclometalation

(40) Klein, C.; Nazeeruddin, M. K.; Liska, P.; Di Censo, D.; Hirata, N.; Palomares, E.; Durrant, J. R.; Grätzel, M. Engineering of a novel ruthenium sensitizer and its application in dye-sensitized solar cells for conversion of sunlight into electricity. Inorg. Chem. 2005, 44 (2), $178-180$.

(41) Yanagida, M.; Singh, L. P.; Sayama, K.; Hara, K.; Katoh, R.; Islam, A.; Sugihara, H.; Arakawa, H.; Nazeeruddin, M. K.; Grätzel, M. A new efficient photosensitizer for nanocrystalline solar cells: synthesis and characterization of cis-bis(4,7-dicarboxy-1,10-phenanthroline)dithiocyanato ruthenium(II). J. Chem. Soc., Dalton Trans. 2000, 16, $2817-2822$.

(42) Yanagida, M.; Islam, A.; Tachibana, Y.; Fujihashi, G.; Katoh, R.; Sugihara, H.; Arakawa, H. Dye-sensitized solar cells based on nanocrystalline $\mathrm{TiO}_{2}$ sensitized with a novel pyridylquinoline ruthenium(II) complex. New J. Chem. 2002, 26 (8), 963-965.

(43) Islam, A.; Hara, K.; Singh, L. P.; Katoh, R.; Yanagida, M.; Murata, S.; Takahashi, Y.; Sugihara, H.; Arakawa, H. Dual electron injection from charge-transfer excited states of $\mathrm{TiO}_{2}$-anchored $\mathrm{Ru}(\mathrm{II})$ 4,4'-dicarboxy-2,2'-biquinoline complex. Chem. Lett. 2000, 5, 490-491.

44) Kukrek, A.; Wang, D.; Hou, Y.; Zong, R.; Thummel, R. Photosensitizers containing the 1,8-naphthyridyl moiety and their use in dye-sensitized solar cells. Inorg. Chem. 2006, 45 (25), 10131-10137.

(45) Argazzi, R.; Bignozzi, C. A.; Hasselmann, G. M.; Meyer, G. J. Efficient light-to-electrical energy conversion with dithiocarbamate ruthenium polypyridyl sensitizers. Inorg. Chem. 1998, 37 (18), 45334537.

(46) Nazeeruddin, M. K.; Muller, E.; Humphry-Baker, R.; Vlachopoulos, N.; Grätzel, M. Redox regulation in ruthenium(II) polypyridyl complexes and their application in solar energy conversion. J. Chem. Soc., Dalton Trans. 1997, 23, 4571-4578.

(47) Ruile, S.; Kohle, O.; Pettersson, H.; Grätzel, M. Unusual properties of ruthenium(II) diphenylcyanamide complexes: chemistry and application as sensitizers of nanocrystalline $\mathrm{TiO}_{2}$. New J. Chem. 1998, 22 (1), 25-31.

(48) Islam, A.; Sugihara, H.; Yanagida, M.; Hara, K.; Fujihashi, G.; Tachibana, Y.; Katoh, R.; Murata, S.; Arakawa, H. Efficient panchromatic sensitization of nanocrystalline $\mathrm{TiO}_{2}$ films by beta-diketonato ruthenium polypyridyl complexes. New J. Chem. 2002, 26 (8), 966-968.

(49) Albrecht, M.; van Koten, G. Platinum group organometallics based on "pincer" complexes: Sensors, switches, and catalysts. Angew. Chem., Int. Ed. 2001, 40 (20), 3750-3781.

(50) Barigelletti, F.; Ventura, B.; Collin, J. P.; Kayhanian, R.; Gavina, P.; Sauvage, J. P. Electrochemical and spectroscopic properties of cyclometallated and non-cyclometallated ruthenium(II) complexes containing sterically hindering ligands of the phenanthroline and terpyridine families. Eur. J. Inorg. Chem. 2000, 1, 113-119.

(51) Collin, J. P.; Gavina, P.; Heitz, V.; Sauvage, J. P. Construction of one-dimensional multicomponent molecular arrays: Control of electronic and molecular motions. Eur. J. Inorg. Chem. 1998, 1, 1-14.

(52) Kui, S. C. F.; Sham, I. H. T.; Cheung, C. C. C.; Ma, C. W.; Yan, B. P.; Zhu, N. Y.; Che, C. M.; Fu, W. F. Platinum(II) complexes with pi-conjugated, naphthyl-substituted, cyclometalated ligands (RC $\mathrm{N} \mathrm{N}$ ): Structures and photo- and electroluminescence. Chem.-Eur. J. 2007, 13 (2), 417-435.

(53) Cocchi, M.; Virgili, D.; Fattori, V.; Rochester, D. L.; Williams, J. A. G. $\mathrm{N}^{\wedge} \mathrm{C}^{\wedge} \mathrm{N}$-coordinated platinum(II) complexes as phosphorescent emitters in high-performance organic light-emitting devices. Adv. Funct. Mater. 2007, 17 (2), 285-289.

(54) Wilkinson, A. J.; Puschmann, H.; Howard, J. A. K.; Foster, C. E.; Williams, J. A. G. Luminescent complexes of iridium(III) containing $\mathrm{N}$ boolean AND $\mathrm{C}$ boolean AND N-coordinating terdentate ligands. Inorg. Chem. 2006, 45 (21), 8685-8699. itself has a strong effect on the photophysical properties of the resulting complexes. ${ }^{55}$ Additionally, it changes the overall charge on the complex, which has consequences for electron transfer processes and possible charge buildup. Previously we have demonstrated for the first time that cyclometalated ruthenium complexes are a promising new class of pigments for dye-sensitized solar cells. ${ }^{56}$ It was shown that cyclometalated complexes with a $\mathrm{C}, \mathrm{N}, \mathrm{N}^{\prime}$-bonding motif have bathochromic-shifted absorption features and are efficient optical sensitizers for $\mathrm{TiO}_{2}$. More recently also others have used cycloruthenated compounds to achieve impressively efficient DSSC devices. ${ }^{57}$

In the present study, the influence of the tridentate donor atom pattern, i.e., $\mathrm{N}, \mathrm{N}^{\prime}, \mathrm{N}^{\prime \prime}$ vs $\mathrm{N}, \mathrm{C}, \mathrm{N}^{\prime}$ vs $\mathrm{C}, \mathrm{N}, \mathrm{N}^{\prime}$, on the electronic, optical, and sensitizing properties is investigated. The photocurrent action spectra for an extended series of cyclometalated dyes are related to those obtained for the non-cyclometalated analogue as well as to the standard N719. In an effort to elucidate the origin of the resulting discrepancies, we used both experimental and computational results to investigate the properties of these complexes in relation to their possibilities as sensitizers for dye-sensitized solar cells.

\section{Results and dicsussion}

To investigate the influence of cyclometalation on the sensitizing properties in a series of complexes (see Chart 1), a ligand series based on the neutral tridentate $2,2^{\prime}: 6^{\prime}, 2^{\prime \prime}$ terpyridine ligand (tpy) was studied. The $\mathrm{N}, \mathrm{N}^{\prime}, \mathrm{N}^{\prime \prime}$-coordinating tpy ligand is known for its ability to form highly stable complexes with ruthenium, and some of its complexes are known sensitizers for $\mathrm{TiO}_{2} \cdot{ }^{13,58}$ In the other ligands one of the nitrogen atoms has been replaced by a monoanionic carbon center in either the inner or the outer pyridine ring. The resulting $\mathrm{N}^{\wedge} \mathrm{C}(\mathrm{H})^{\wedge} \mathrm{N}$ and $\mathrm{C}(\mathrm{H})^{\wedge} \mathrm{N}^{\wedge} \mathrm{N}$ arene ligands should display a different interaction with the ruthenium, as the resulting cyclometalated $\mathrm{N}, \mathrm{C}, \mathrm{N}^{\prime}$ - and $\mathrm{C}, \mathrm{N}, \mathrm{N}^{\prime}$-coordinated complexes are subject to distinctively different symmetry operations. The benchmark compound N719 (Chart 1, $\mathrm{TBA}=$ tetrabutylammonium), containing a bidentate, $\mathrm{N}, \mathrm{N}^{\prime}$ coordinating 2,2'-bipyridine (bpy), was used as a reference compound in the solar cell testing.

Ligands 5, 6, and 7 were prepared using adapted literature procedures. The ligand $\mathrm{EtO}_{2} \mathrm{C}-\mathrm{N}^{\wedge} \mathrm{N}^{\wedge} \mathrm{N}(5)$ was prepared from the corresponding 2,6-dibromopyridine precursor using palladium-catalyzed Stille $\mathrm{C}-\mathrm{C}$ coupling methodology. This precursor was prepared by bromination of commercially obtained citrazinic acid using in situ formed $\mathrm{POBr}_{3}$. In a similar fashion, $\mathrm{MeO}_{2} \mathrm{C}-\mathrm{N}^{\wedge} \mathrm{C}(\mathrm{H})^{\wedge} \mathrm{N}$ (6) was prepared from the methyl-2,6-dibromobenzoic acid precursor, which could easily be

(55) Koizumi, T. A.; Tomon, T.; Tanaka, K. Synthesis, structures and electrochemical properties of ruthenium (II) complexes bearing bidentate 1,8-naphthyridine and terpyridine analogous (N,N,C)-tridentate ligands. J. Organomet. Chem. 2005, 690 (19), 4272-4279.

(56) Wadman, S. H.; Kroon, J. M.; Bakker, K.; Lutz, M.; Spek, A. L.; van Klink, G. P. M.; van Koten, G. Cyclometalated ruthenium complexes for sensitizing nanocrystalline $\mathrm{TiO}_{2}$ solar cells. Chem. Commun. 2007, 19, 1907-1909.

(57) Bessho, T.; Yoneda, E.; Yum, J.-H.; Guglielmi, M.; Tavernelli, I.; Imai, H.; Rothlisberger, U.; Nazeeruddin, M. K.; GraÌtzel, M. New paradigm in molecular engineering of sensitizers for solar cell applications. J. Am. Chem. Soc. 2009, 131 (16), 5930-5934.

(58) Beley, M.; Bignozzi, C. A.; Kirsch, G.; Alebbi, M.; Raboin, J. C. New ruthenium bisterpyridinyl complexes, as efficient sensitizers of nanocrystalline, $\mathrm{TiO}_{2}$ films. Inorg. Chim. Acta 2001, 318 (1-2), 197-200. 
Chart 1. Molecular Structure of Dyes N719, 1, 2, 3, and 4

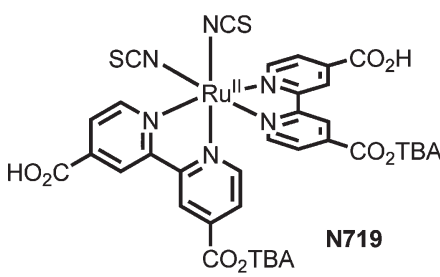

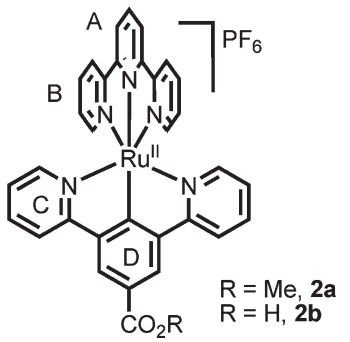

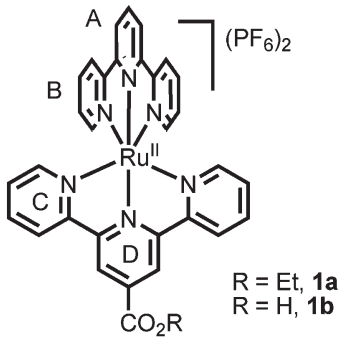

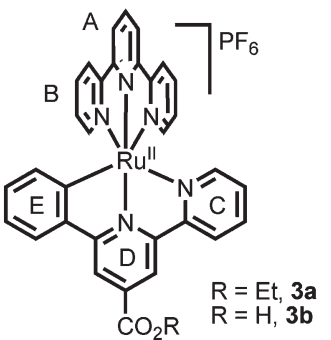

Scheme 1. Synthesis of Complexes 1a, 2a, 3a, and 4a

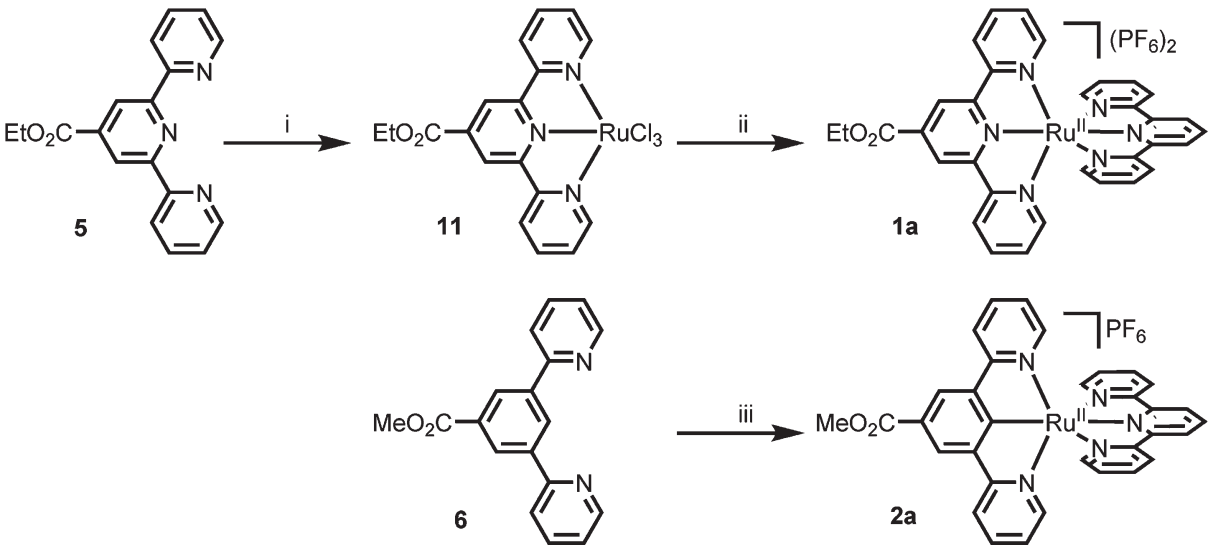

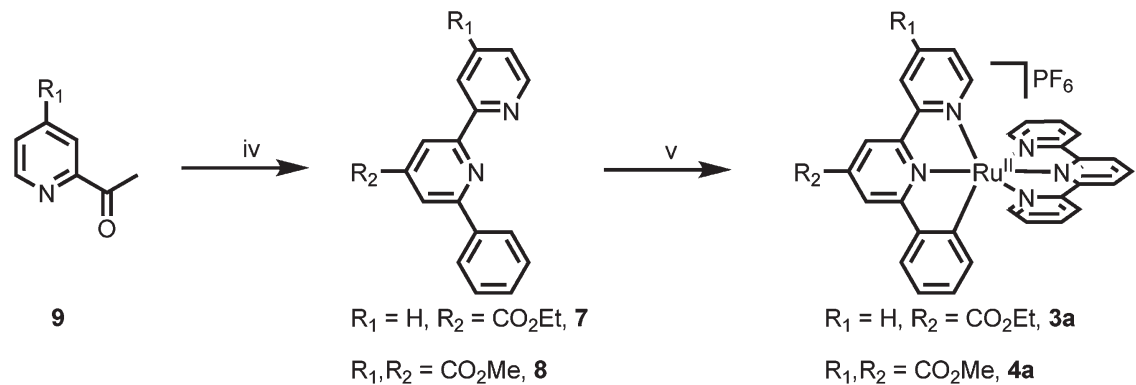

a (i) $\mathrm{RuCl}_{3} \cdot 3 \mathrm{H}_{2} \mathrm{O}$, EtOH, reflux, $2 \mathrm{~h}$, (ii) (1) $\mathrm{AgBF}_{4}$, acetone, reflux $2 \mathrm{~h}$, (2) tpy, EtOH, reflux $16 \mathrm{~h}$, (3) $\mathrm{KPF}_{6}$, (iii) (1) $\left[\mathrm{RuCl}_{3}(\mathrm{tpy})\right], \mathrm{AgBF}_{4}$, acetone, reflux, $2 \mathrm{~h},(2) 6, n-\mathrm{BuOH}$, reflux $16 \mathrm{~h}$, (3) $\mathrm{KPF}_{6}$, (iv) (1) $\mathrm{I}_{2}$, pyridine, heat, 9 min, (2) $\mathrm{NH}_{4} \mathrm{OAc}, \mathrm{MeOH}$, reflux, $16 \mathrm{~h},(3) \mathrm{H}_{2} \mathrm{SO}_{4}, \mathrm{MeOH}$, reflux, $20 \mathrm{~h}$, (v) (1) $\left[\mathrm{RuCl}_{3}\left(\right.\right.$ tpy)], $\mathrm{N}$-methylmorpholine, $\mathrm{MeOH}, \mathrm{H}_{2} \mathrm{O}$, reflux, $16 \mathrm{~h}$, (2) $\mathrm{KPF}_{6}$.

obtained via selective bromination of methyl anthranilate. In contrast, the ligands $\mathrm{EtO}_{2} \mathrm{C}-\mathrm{C}(\mathrm{H})^{\wedge} \mathrm{N}^{\wedge} \mathrm{N}(7)$ and $\left(\mathrm{MeO}_{2}\right)_{2}-$ $\mathrm{C}(\mathrm{H})^{\wedge} \mathrm{N}^{\wedge} \mathrm{N}(\mathbf{8})$ were synthesized following Krönke ${ }^{59}$ methodology. Ligand 7 was prepared by reacting 1-(2-pyridinylcarbonyl)pyridinium iodide with the commercially obtained chalcone benzoylacrilic acid in the presence of ammonium acetate as a nitrogen donor. Similarly, ligand $\mathbf{8}$ was obtained from the reaction of 1-(2-(4-methylcarboxyl)pyridinyl)carbonyl)pyridinium iodide (10) with benzoylacrilic acid,

(59) Kroehnke, F. Syntheses using pyridinium salts. 5. The specific synthesis of pyridines and oligopyridines. Synthesis 1976, 1, 1-24.
Scheme 1. Compound $\mathbf{1 0}$ was prepared in pyridine by iodination of methyl 2-acetylisonicotinate (9), which was obtained by acetylation of methyl isonicotinate.

The complexes were prepared and purified in the esterprotected form for solubility reasons, Scheme 1. After complete characterization and analysis, the esters were deprotected to the corresponding acids to perform solar cell testing.

The dicationic complex $\left[\mathrm{Ru}\left(\mathrm{EtO}_{2} \mathrm{C}-\mathrm{N}^{\wedge} \mathrm{N}^{\wedge} \mathrm{N}\right)(\mathrm{tpy})\right]\left(\mathrm{PF}_{6}\right)_{2}$, 1a, was prepared by reaction of $\left[\mathrm{RuCl}_{3}(\mathbf{5})\right]$, 11, with $\mathrm{AgBF}_{4}$ in acetone, followed by reaction of the resulting solvento complex with terpyridine in EtOH solution. We found this procedure to be preferred over reaction of the ruthenium 
Table 1. Cyclic Voltammetry Data ${ }^{a}$ for N719, 1a, 2a, 3a, and 4a

\begin{tabular}{lcccc}
\hline & \multicolumn{4}{c}{$E_{1 / 2}(\mathrm{~V})\left(\Delta E_{\mathrm{p}}(\mathrm{mV})\right)$} \\
\cline { 2 - 5 } complex & 1st oxidation & 1st reduction & 2nd reduction & $\Delta E_{\text {ox-red }}$ \\
\hline N719 & $0.48^{62}$ & $-1.17^{b, 63}$ & & 1.65 \\
1a & $0.95(68)$ & $-1.45(64)$ & $-1.85(76)$ & 2.40 \\
2a & $0.25(63)$ & $-1.91(64)$ & & 2.16 \\
3a & $0.22(63)$ & $-1.81(61)$ & $-2.17(77)$ & 2.03 \\
4a & $0.26(60)$ & $-1.64(67)$ & $-2.09(70)$ & 1.90
\end{tabular}

${ }^{a}$ Data collected in $\mathrm{MeCN}$ at $100 \mathrm{mV} / \mathrm{s}$; potentials reported vs ferrocene/ferrocenium $\left(\mathrm{Fc} / \mathrm{Fc}^{+}\right)$used as internal standard. ${ }^{b}$ Reported vs SCE, corrected to vs $\mathrm{Fc} / \mathrm{Fc}^{+}$by subtraction of $0.35 \mathrm{~V}$. ${ }^{64}$

precursor $\left[\mathrm{RuCl}_{3}\right.$ (tpy)] with ligand $5 .^{60} \mathrm{Tpy}$ is a more electron rich ligand compared to $\mathbf{5}$, leading to a cleaner, higher yielding reaction when $\mathbf{1 1}$ is used as a more reactive intermediate and reacting this with tpy.

The monocationic complex $\left[\mathrm{Ru}\left(\mathrm{MeO}_{2} \mathrm{C}-\mathrm{N}^{\wedge} \mathrm{C}^{\wedge} \mathrm{N}\right)(\right.$ tpy) $]-$ $\left(\mathrm{PF}_{6}\right), \mathbf{2 a}$, was prepared by activation of $\left[\mathrm{RuCl}_{3}(\mathrm{tpy})\right]$ with $\mathrm{AgBF}_{4}$ in acetone and subsequent reaction with 6 in $n-\mathrm{BuOH}$. In this reaction, the use of $n-\mathrm{BuOH}$ is preferred over $\mathrm{EtOH}$, as it suppresses a side reaction, which yields a complex in which $\mathbf{6}$ is coordinated in a C,N-bidentate fashion, and is cyclometalated at the 3-position rather than at the desired 1position.

When $\left[\mathrm{Ru}\left(\mathrm{EtO}_{2} \mathrm{C}-\mathrm{C}^{\wedge} \mathrm{N}^{\wedge} \mathrm{N}\right)(\right.$ tpy $\left.)\right]\left(\mathrm{PF}_{6}\right), 3 \mathbf{a}$, is prepared using the same protocol, reacting 7 with activated $\left[\mathrm{RuCl}_{3}(\mathrm{tpy})\right]$, a nonmetalated product is obtained as the major product. In this complex, 7 is coordinated in an $\mathrm{N}, \mathrm{N}^{\prime}$-bidentate fashion, as previously discussed for the nonsubstituted analogue. ${ }^{61}$ Therefore, $\mathbf{3} \mathbf{a}$ was synthesized by reacting $\left[\mathrm{RuCl}_{3}(\mathrm{tpy})\right]$ directly with 7 in $\mathrm{EtOH}$ in the presence of $N$-methylmorpholine as sacrificial reducing agent. Although also this procedure still resulted in the formation of small amounts of the side product, these could easily be removed by chromatography. We did not use aqueous $\mathrm{MeOH}$ or DMF, which are commonly used solvents favoring exclusive cyclometalation, ${ }^{61}$ because in these solvents transand de-esterification as well as decomposition were observed. $\left[\mathrm{Ru}\left(4,4^{\prime}-\left(\mathrm{MeO}_{2} \mathrm{C}\right)_{2}-\mathrm{C}^{\wedge} \mathrm{N}^{\wedge} \mathrm{N}\right)(\mathrm{tpy})\right]\left(\mathrm{PF}_{6}\right), \mathbf{4 a}$, was prepared by reacting 8 with $\left[\mathrm{RuCl}_{3}(\right.$ tpy) $]$ in $\mathrm{MeOH}$ in the presence of $N$ methylmorpholine.

Deprotection of the acids could be achieved by reaction with triethylamine in aqueous DMF. However, for the deprotection of $\mathbf{2 a}$ it was necessary to use sodium hydroxide as base. This is a result of the decreased acidity of the carboxylic acid moiety in $\mathbf{2} \mathbf{b}$ compared to the same group in $\mathbf{1 b}$ and $\mathbf{3 b}$, vide infra.

Table 1 contains data obtained from cyclic voltammetry $(\mathrm{CV})$ in $\mathrm{MeCN}$ solution reported relative to ferrocene. The oxidation potential of $\mathbf{1 a}(0.95 \mathrm{~V})$ is slightly anodically shifted compared to $\left[\mathrm{Ru}(\mathrm{tpy})_{2}\right]^{2+}(0.92 \mathrm{~V})$ as a result of the

(60) Bolink, H. J.; Cappelli, L.; Coronado, E.; Gavina, P. Observation of electroluminescence at room temperature from a ruthenium(II) bis-terpyridine complex and its use for preparing light-emitting electrochemical cells. Inorg. Chem. 2005, 44 (17), 5966-5968.

(61) Constable, E. C.; Hannon, M. J. Solvent effects in the reactions of 6-phenyl-2,2'-bipyridine with ruthenium(II). Inorg. Chim. Acta 1993, $211(1), 101-110$.

(62) Bond, A. M.; Deacon, G. B.; Howitt, J.; MacFarlane, D. R.; Spiccia, L.; Wolfbauer, G. Voltammetric determination of the reversible redox potential for the oxidation of the highly surface active polypyridyl ruthenium photovoltaic sensitizer cis-Ru(II)(dcbpy $)_{2}(\mathrm{NCS})_{2}$. J. Electrochem. Soc. 1999, 146 (2), 648-656.

(63) Onozawa-Komatsuzaki, N.; Kitao, O.; Yanagida, M.; Himeda, Y.; Sugihara, H.; Kasuga, K. Molecular and electronic ground and excited structures of heteroleptic ruthenium polypyridyl dyes for nanocrystalline $\mathrm{TiO}_{2}$ solar cells. New J. Chem. 2006, 30 (5), 689-697.

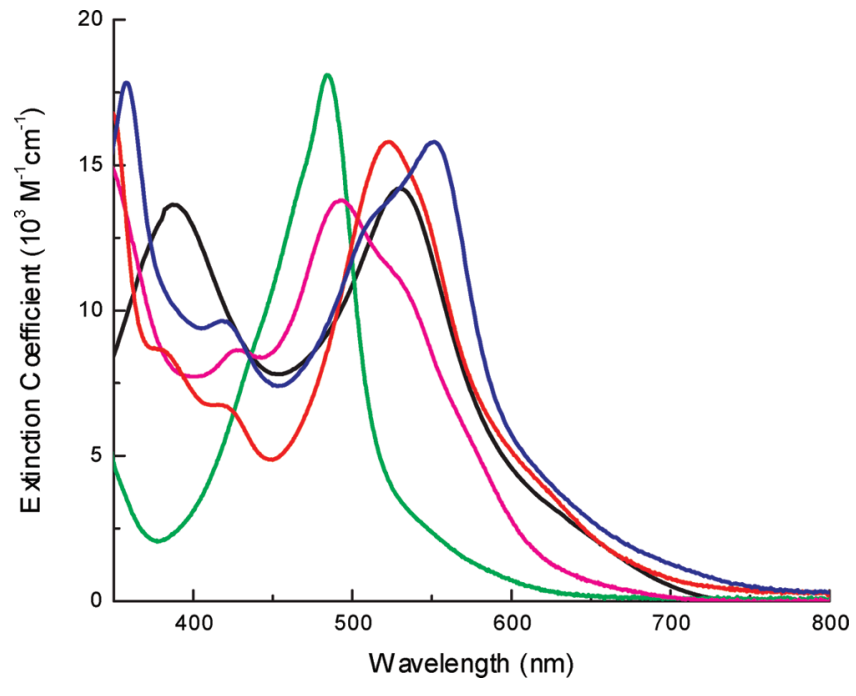

Figure 1. UV-vis spectra of N719 (black), 1a (green), 2a (magenta), 3a (red), and 4a (blue) in $\mathrm{MeCN}$ solution.

electron-withdrawing properties of the ester moiety. ${ }^{65}$ Cyclometalation results in a cathodic shift of 0.70 and $0.73 \mathrm{~V}$ for $\mathbf{2 a}$ and $\mathbf{3 a}$, respectively. The oxidation potential of $\mathbf{4 a}(0.26 \mathrm{~V})$ is slightly more positive than that of $\mathbf{3} \mathbf{a}$ as a result of the influence of the second carboxylate moiety. The oxidation potential for 1a is also anodically shifted compared to N719, but to a lesser extent, as a result of the strong $\sigma$-donor properties of the NCS ligands present in N719.

The $2+/ 1+$ redox potential of $\mathbf{1 a}(-1.45 \mathrm{~V})$ is anodically shifted relative to $\left[\mathrm{Ru}(\text { tpy })_{2}\right]^{2+}(-1.67 \mathrm{~V})$, reflecting the electronwithdrawing properties of the carboxylate moiety. ${ }^{65}$ As the reduction is located on the substituted ligand, the effect is larger for the $2+/ 1+$ redox potential compared to the small shift in the $2+/ 3+$ redox potential. Both $\mathbf{2} \mathbf{a}$ and $\mathbf{3} \mathbf{a}$ are reduced at potentials substantially more negative than $\left[\mathrm{Ru}(\mathrm{tpy})_{2}\right]^{2+}$, in line with a more electron rich metal center. In $\mathbf{4 a}$, the electron-accepting ability of the second carboxylate group results in a less negative potential compared to $\mathbf{3 a}$.

Figure 1 shows the electronic absorption spectra of the complexes in MeCN solution as well as the spectrum of N719 for comparison. The spectrum of $\mathbf{1 a}$ is dominated by an intense and sharp metal-to-ligand charge transfer (MLCT) transition $\left(\lambda_{\max }=487 \mathrm{~nm}, \varepsilon=18.0 \times 10^{3} \mathrm{M}^{-1} \mathrm{~cm}^{-1}\right)$. This absorption is slightly red-shifted compared to $\left[\mathrm{Ru}(\mathrm{tpy})_{2}\right]^{2+}$ $\left(\lambda_{\max }=474 \mathrm{~nm}\right),{ }^{65}$ reflecting the effect of the electronwithdrawing properties of the carboxylate moiety. Replacing a nitrogen atom with an anionic carbon atom significantly changes the electronic absorption spectra. The spectra of both $\mathbf{2 a}\left(\lambda_{\max }=492 \mathrm{~nm}, \varepsilon=13.7 \times 10^{3} \mathrm{M}^{-1} \mathrm{~cm}^{-1}\right)$ and $\mathbf{3 a}$ $\left(\lambda_{\max }=523 \mathrm{~nm}, \varepsilon=15.8 \times 10^{3} \mathrm{M}^{-1} \mathrm{~cm}^{-1}\right)$ show a distinct broadening and red shift of the absorption features. The red shift is especially pronounced for the $\mathrm{C}, \mathrm{N}, \mathrm{N}^{\prime}$-cyclometalated complex 3a. Both 2a and 3a display a number of shoulders

(64) Kolthoff, I. M.; Thomas, F. G. Electrode potentials in acetonitrile. Estimation of the liquid junction potential between acetonitrile solutions and the aqueous saturated calomel electrode. J. Phys. Chem. 1965, $69(9), 3049-58$.

(65) Maestri, M.; Armaroli, N.; Balzani, V.; Constable, E. C.; Thompson, A. M. W. C. Complexes of the Ruthenium(II)-2, $2^{\prime} / 6^{\prime}, 2^{\prime \prime}$ Terpyridine Family - Effect of Electron-Accepting and Electron-Donating Substituents on the Photophysical and Electrochemical Properties. Inorg. Chem. 1995, 34 (10), 2759-2767. 


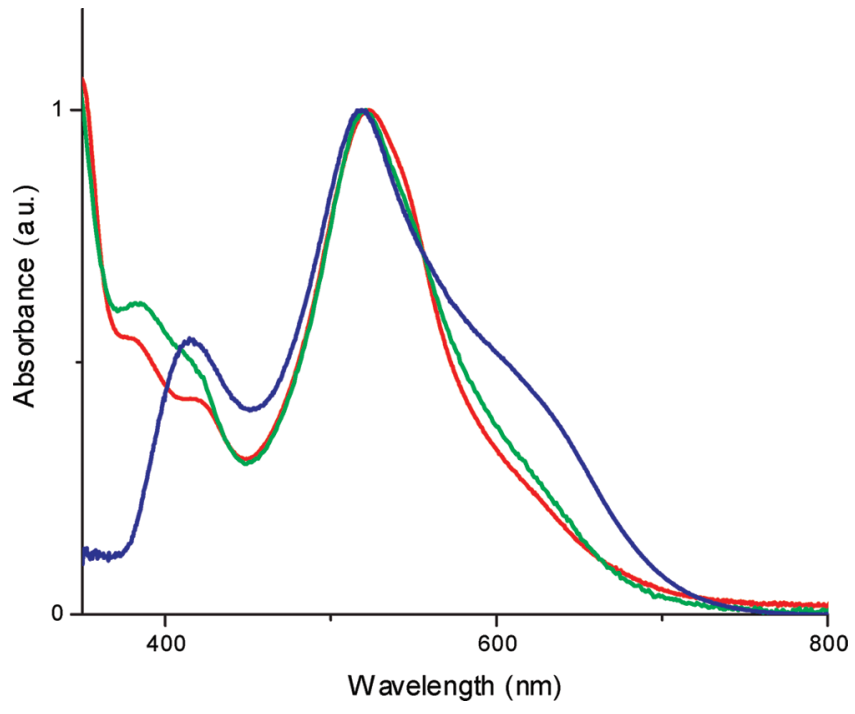

Figure 2. Normalized UV-vis spectra of 3a (red, $\mathrm{MeCN}$ solution), $\mathbf{3 b}$ (green, $1: 3 \mathrm{H}_{2} \mathrm{O} / \mathrm{DMSO}$ solution), and $\mathbf{3 b}$ absorbed on $\mathrm{TiO}_{2}$ (blue) measured in diffuse reflectance mode.

presumably resulting from the presence of a multitude of electronic transitions. It is interesting to note that the absorption maximum of $\mathbf{3 a}$ is roughly equal to that of $\mathbf{N 7 1 9}\left(\lambda_{\max }=530 \mathrm{~nm}, \varepsilon=14.2 \times 10^{3} \mathrm{M}^{-1} \mathrm{~cm}^{-1}\right),{ }^{12}$ and to a somewhat lesser extent this also holds for $\mathbf{2 a}$, although $\Delta E_{\text {ox-red }}$ is smallest for $\mathbf{N 7 1 9}$. The red shift that is obtained in N719 by the coordination of two thiocyanate groups seems to be reproduced by the single anionic carbon-to-ruthenium bond, replacing two potentially labile monodentate ligands ${ }^{66}$ by a single moiety stabilized as a tridentate chelate. Addition of a second carboxylate moiety on the cyclometalating moiety, i.e., on going from 3a to $\mathbf{4 a}\left(\lambda_{\max }=552 \mathrm{~nm}, \varepsilon=\right.$ $\left.15.8 \times 10^{3} \mathrm{M}^{-1} \mathrm{~cm}^{-1}\right)$ resulted in a further red shift. This correlates well with the decreasing difference between the respective reduction and oxidation potentials. All complexes are photostable in the original $\mathrm{Ru}(\mathrm{II})$ oxidation state and do not show decomposition upon prolonged irradiation. N719 is known to decompose quickly in its oxidized state ${ }^{62}$ through loss of the thiocyanate ligand. ${ }^{67}$ Contrarily, 2a, 3a, and $4 \mathbf{a}$ can be chemically oxidized by $\mathrm{Ce}^{\mathrm{IV}}$ in $\mathrm{MeCN}$ solution and are stable in the resulting $\mathrm{Ru}$ (III) state for at least several weeks under ambient light.

Deprotection of the esters to their corresponding acids did not significantly alter their optical absorption spectra; see Figure 2. Grafting these complexes on anatase- $\mathrm{TiO}_{2}$ did not substantially change the spectra, but did result in a slight broadening and a small increase in the relative intensity of the red tail. This was considered desirable, as it increases the overlap with the solar spectrum and should lead to larger photocurrents. These results indicate that the electronic properties of the prepared complexes are not significantly altered during deprotection or grafting and that the more soluble, ester-protected complexes are an adequate model for the free-acid complexes grafted onto the $\mathrm{TiO}_{2}$.

(66) Hecker, C. R.; Fanwick, P. E.; Mcmillin, D. R. Evidence for Dissociative Photosubstitution Reactions of $\left[\mathrm{Ru}(\mathrm{Trpy})(\mathrm{Bpy})\left(\mathrm{NCCH}_{3}\right)\right]^{2+}$ Crystal and Molecular-Structure of $[\mathrm{Ru}(\mathrm{Trpy})(\mathrm{Bpy})(\mathrm{Py})]\left(\mathrm{Pf}_{6}\right)_{2} \cdot\left(\mathrm{CH}_{3}\right)_{2} \mathrm{CO}$. Inorg. Chem. 1991, 30 (4), 659-666.

(67) Grätzel, M. Solar energy conversion by dye-sensitized photovoltaic cells. Inorg. Chem. 2005, 44 (20), 6841-6851.

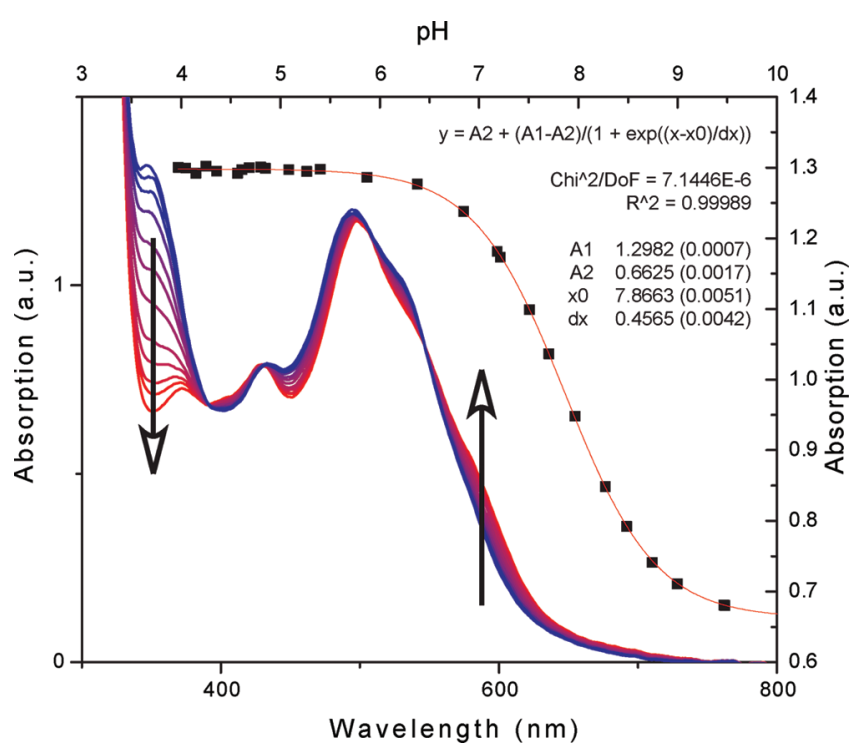

Figure 3. $\mathrm{pH}$ dependence of the optical absorption of $\mathbf{2 b}$ in $1: 3$ $\mathrm{H}_{2} \mathrm{O} / \mathrm{DMSO}$ and the absorbance at $350 \mathrm{~nm}$ as a function of $\mathrm{pH}$. Arrows indicate change upon increasing $\mathrm{pH}$.

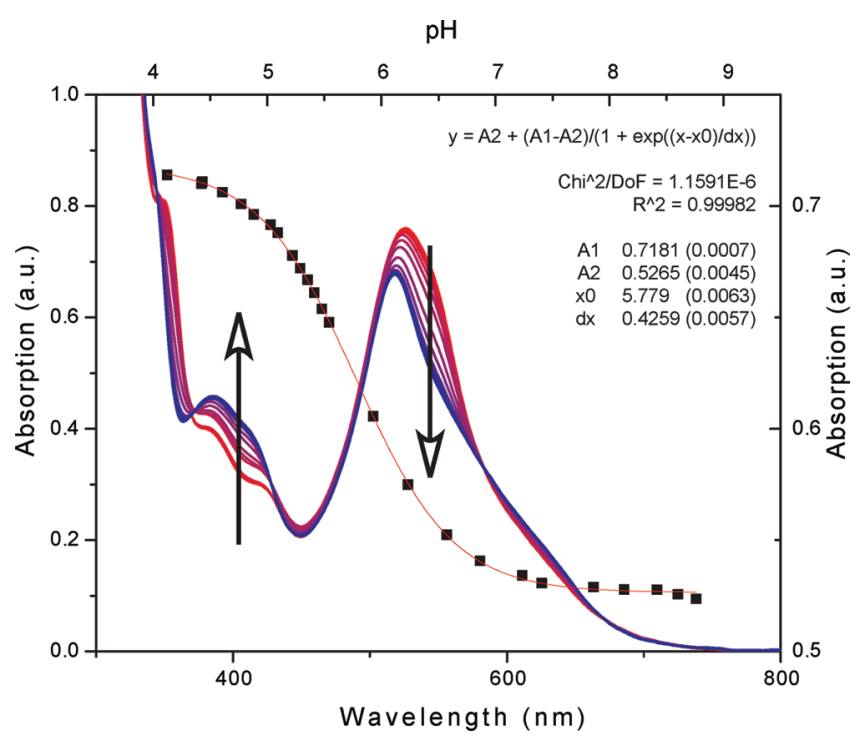

Figure 4. $\mathrm{pH}$ dependence of the optical absorption of $\mathbf{3 b}$ in $1: 3$ $\mathrm{H}_{2} \mathrm{O} /$ DMSO and the absorbance at $540 \mathrm{~nm}$ as a function of $\mathrm{pH}$. Arrows indicate change upon increasing $\mathrm{pH}$.

The relative inertness of $\mathbf{2} \mathbf{a}$ compared to $\mathbf{3 a}$ and $\mathbf{1 a}$ in the base-catalyzed deprotection prompted us to determine the respective $\mathrm{p} K_{\mathrm{a}}$ values by means of the spectroscopic method. In this method, spectral changes are observed that are a result of protonation or deprotonation of the acid. Because the complexes are only sparsely soluble in $\mathrm{H}_{2} \mathrm{O}$, the $\mathrm{p} K_{\mathrm{a}}$ was obtained by linear extrapolation of the values obtained in $3: 1,1: 1$, and $1: 3 \mathrm{H}_{2} \mathrm{O} / \mathrm{DMSO}$ mixtures. Figure 3 displays the spectroscopic changes of $\mathbf{2 b}$ in acidified 1:3 $\mathrm{H}_{2} \mathrm{O} / \mathrm{DMSO}$ solution upon alkalification with $\mathrm{NaOH}$, as well as the absorbance at $350 \mathrm{~nm}$ as a function of $\mathrm{pH}$. This procedure could not be followed for the determination of $\mathbf{1 b}, \mathbf{3 b}$ (Figure 4 ), and $\mathbf{4 b}$, as they slowly decomposed in the acidic medium. These measurements started from an alkaline solution and were carefully acidified with $\mathrm{HCl}$. The $\mathrm{p} K_{\mathrm{a}}$ of 4.3 for $\mathbf{2} \mathbf{b}$ is high compared to 2.2 and 2.9 for $\mathbf{1 b}$ and $\mathbf{3 b}$, respectively, and is nicely in line with 


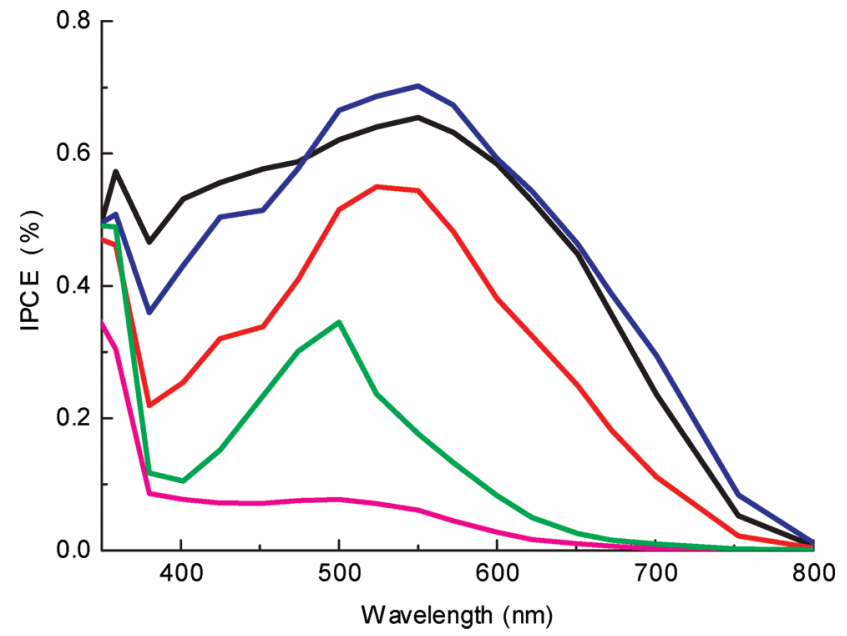

Figure 5. Photocurrent action spectra of N719 (black), 1b (green), $\mathbf{2 b}$ (magenta), $\mathbf{3 b}$ (red), and $\mathbf{4 b}$ (blue) in a $\mathrm{TiO}_{2}$ solar cell using $0.5 \mathrm{M} \mathrm{LiI}$ and $0.05 \mathrm{M} \mathrm{I}_{2}$ in $\gamma$-butyrolactone as electrolyte.

the stability of the corresponding ester. For $\mathbf{4 b}$ values of 3.0 and 1.9 are obtained for the two carboxylic acids, respectively. These values can be compared to the values obtained for N719 in 5:1 $\mathrm{H}_{2} \mathrm{O}$ to EtOH of 1.5 and 3.0 for both carboxylic acid moieties. ${ }^{68}$ Interestingly, we could consider the complex $\mathbf{2 b}$ as a parasubstituted benzoic acid. By doing so, we can determine qualitatively the Hammett parameter ${ }^{69}$ for the whole complex. The $\mathrm{p} K_{\mathrm{a}}$ value of 4.3 corresponds to $\sigma_{\mathrm{p}}=-0.1$, indicating slight electrondonating properties.

For the photovoltaic measurements, dye-sensitized solar cells (DSSCs) were produced on standardized masterplates in which a constant layer thickness and electrode quality could be ensured. It was the primary aim of this study to investigate the potential of these complexes as sensitizers in DSSCs, and for this reason, a convenient electrolyte, consisting of $\mathrm{LiI}(0.5 \mathrm{M})$ and $\mathrm{I}_{2}(0.05 \mathrm{M})$ in $\gamma$-butyrolactone, was employed. More complex electrolytes generally increase efficiency by sacrificing photocurrent for an increase in voltage and fill factor and are usually optimized for cells stained with N719. The simpler electrolyte used here gives a more unbiased demonstration of the sensitizing capabilities of the corresponding complexes.

The photocurrent action spectra of the prepared complexes, as well as that obtained for N719, are shown in Figure 5. It is clear that the spectral features observed for $\mathbf{1 b}$ in solution are also visible in the incident photon-to-current conversion efficiency (IPCE) curve. The IPCE has an onset around $650 \mathrm{~nm}$ and peaks at $35 \%$. This maximum in current is observed around $500 \mathrm{~nm}$, where the absorption of the complex also peaks in solution. Compared to $\mathbf{1 b}$, a dramatic drop in IPCE is observed for $\mathbf{2 b}$, although it is still an improvement over a bare $\mathrm{TiO}_{2}$ electrode. The photocurrent action spectrum follows the same curve as the electronic absorption in solution, with a maximum of $8 \%$ at $500 \mathrm{~nm}$. The photocurrent action spectrum of $\mathbf{3 b}$, on the

(68) Nazeeruddin, M. K.; Zakeeruddin, S. M.; Humphry-Baker, R.; Jirousek, M.; Liska, P.; Vlachopoulos, N.; Shklover, V.; Fischer, C. H.; Grätzel, M. Acid-base equilibria of $\left(2,2^{\prime}\right.$-bipyridyl-4, $4^{\prime}$-dicarboxylic acid)ruthenium(II) complexes and the effect of protonation on chargetransfer sensitization of nanocrystalline titania. Inorg. Chem. 1999, 38 (26), 6298-6305.

(69) Hansch, C.; Leo, A.; Taft, R. W. A Survey of Hammett Substituent Constants and Resonance and Field Parameters. Chem. Rev. 1991, 91 (2), 165-195. other hand, shows a large improvement over $\mathbf{1 b}$. The IPCE is increased over the entire visible spectrum, reaching a maximum of $55 \%$ at $530 \mathrm{~nm}$ with an onset around $750 \mathrm{~nm}$. The red shift of the IPCE maximum is in agreement with the difference between the respective electronic spectra. The increased red response is an indication that the red-shifted absorption can indeed be utilized to shift the operational threshold of the individual sensitizer toward lower energy. The photoaction spectrum of $\mathbf{4 b}$, in turn, shows a significant improvement over $\mathbf{3 b}$, which can, at least partially, be explained by a more intimate contact of this sensitizer with $\mathrm{TiO}_{2}$ due to the presence of two anchoring moieties. The IPCE peaks at $70 \%$ at $550 \mathrm{~nm}$. Interestingly, the spectral features of the photocurrent action spectra of the solar cells sensitized by the $\mathrm{C}, \mathrm{N}, \mathrm{N}^{\prime}$-cyclometalated dye $\mathbf{4 b}$ and the $\mathrm{N}$, $\mathrm{N}^{\prime}$-bpy-coordinated reference dye $\mathbf{N 7 1 9}$ are very similar; both show an IPCE onset around $800 \mathrm{~nm}$ and peak around $550 \mathrm{~nm}$. Moreover, the photocurrent for $\mathbf{4 b}$, derived by taking the spectral overlap of the action spectrum and the AM1.5 spectrum, is somewhat higher than for the N719-sensitized reference system (12.0 vs $11.5 \mathrm{~mA} / \mathrm{cm}^{2}$ ).

The striking difference observed between the sensitizing capabilities of 2a and 3a prompted us to investigate these complexes using time-dependent density functional theory (TD-DFT) calculations. TD-DFT calculations have previously been used as a tool to investigate the operation of ruthenium sensitizers in DSSCs, ${ }^{70-73}$ for instance the effect of the mode of adsorption to the surface on the open circuit potential. The current calculations were performed on the corresponding methyl esters, $\mathbf{1} \mathbf{a}^{\prime}, \mathbf{2} \mathbf{a}$, and $\mathbf{3} \mathbf{a}^{\prime}$. A complete listing of orbital energies, isodensity plots, and electronic transitions is given in the Supporting Information. The calculated optical absorptions correlate well with the spectrum as measured in $\mathrm{MeCN}$ solution. Both the relative energies and the shapes of the absorptions for $\mathbf{1} \mathbf{a}^{\prime}, \mathbf{2} \mathbf{a}$, and $\mathbf{3} \mathbf{a}^{\prime}$ are in good agreement, albeit slightly blue-shifted, Figure 6.

For the dicationic $\left[\mathrm{Ru}\left(\mathrm{MeO}_{2} \mathrm{C}-\mathrm{N}^{\wedge} \mathrm{N}^{\wedge} \mathrm{N}\right)(\text { tpy) }]^{2+}, \mathbf{1 a}^{\prime}\right.$, the highest occupied molecular orbital (HOMO), HOMO-1, and $\mathrm{HOMO}-2$, corresponding to $\mathrm{Ru}\left(\mathrm{d}_{x y}\right), \mathrm{Ru}\left(\mathrm{d}_{z x}\right)$, and $\mathrm{Ru}$ $\left(\mathrm{d}_{y z}\right)$, are nearly degenerate in energy, as a result of the high symmetry in the hexagonal coordination sphere. The unoccupied molecular orbitals are localized on either of the tpy ligands. Orbitals localized on the ester-functionalized tpy moiety are generally found to be lower in energy than the corresponding orbitals on the tpy moiety. The intense and sharp optical absorption of $\mathbf{1 a}^{\prime}$ is predicted to be of MLCT origin, with contributions to both tpy ligands.

For $\left[\mathrm{Ru}\left(\mathrm{MeO}_{2} \mathrm{C}-\mathrm{N}^{\wedge} \mathrm{C}^{\wedge} \mathrm{N}\right)(\text { tpy) }]^{+}, \mathbf{2} \mathbf{a}\right.$, a different picture is obtained, Figure 6 . The splitting between the HOMO on the one hand and the HOMO-1 and HOMO-2 on the other is increased due to the strong $\sigma$-donor properties of the cyclometalated $\mathrm{MeO}_{2} \mathrm{C}-\mathrm{N}^{\wedge} \mathrm{C}^{\wedge} \mathrm{N}$ ligand. The tpy-based unoccupied

(70) Zhang, X.; Zhang, J.-J.; Xia, Y.-Y. A comparative theoretical investigation of ruthenium dyes in dye-sensitized solar cells. J. Photochem. Photobiol., A 2007, 185 (2-3), 283-288.

(71) Barolo, C.; Nazeeruddin, M. K.; Fantacci, S.; Di Censo, D.; Comte, P.; Liska, P.; Viscardi, G.; Quagliotto, P.; De Angelis, F.; Ito, S.; Grätzel, M. Synthesis, characterization, and DFT-TDDFT computational study of a ruthenium complex containing a functionalized tetradentate ligand. Inorg. Chem. 2006, 45 (12), 4642-4653.

(72) De Angelis, F.; Fantacci, S.; Selloni, A.; Grätzel, M.; Nazeeruddin, M. K. Influence of the sensitizer adsorption mode on the open-circuit potential of dye-sensitized solar cells. Nano Lett. 2007, 7 (10), 3189-3195.

(73) De Angelis, F.; Fantacci, S.; Selloni, A.; Nazeeruddin, M. K.; Grätzel, M. Time-dependent density functional theory investigations on the excited states of $\mathrm{Ru}(\mathrm{II})$-dye-sensitized $\mathrm{TiO}_{2}$ nanoparticles: the role of sensitizer protonation. J. Am. Chem. Soc. 2007, 129 (46), 14156-14157. 


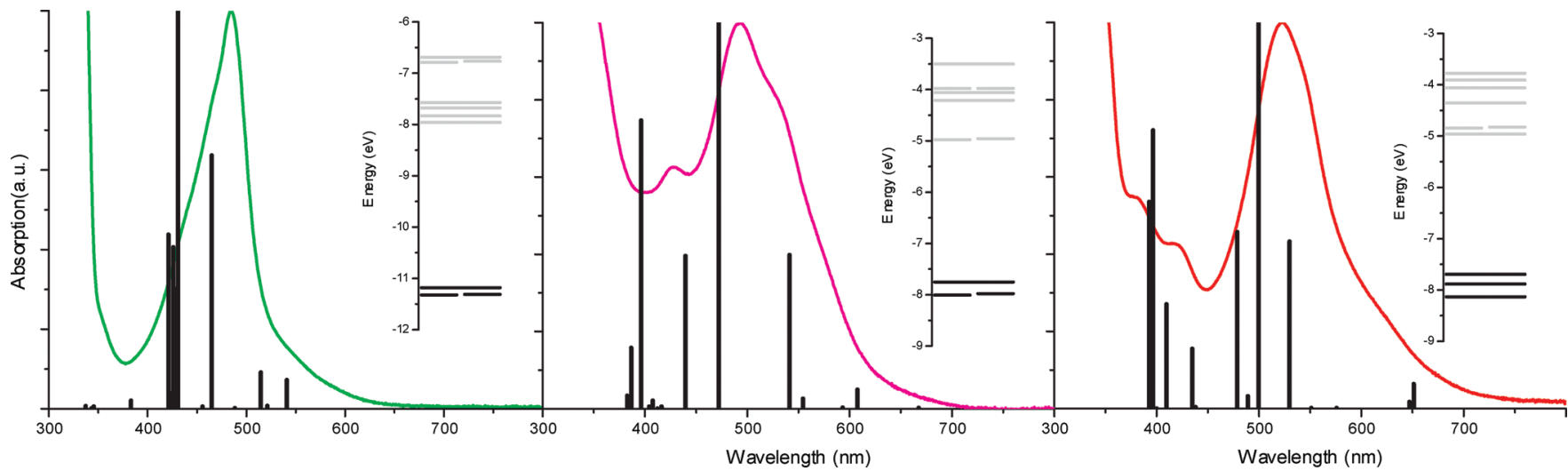

Figure 6. UV-vis spectrum of 1a (left, green), 2a (middle, magenta), and 3a (right, red) in MeCN solution, absorptions predicted by TD-DFT on $\mathbf{1} \mathbf{a}^{\prime}, \mathbf{2} \mathbf{a}$, and $\mathbf{3} \mathbf{a}^{\prime}$ in vacuo (black bars), and orbital energy diagram (insets, occupied and unoccupied MOs represented by black and gray lines, respectively).

molecular orbitals are of lower energy than the $\mathrm{MeO}_{2} \mathrm{C}-\mathrm{N}^{\wedge} \mathrm{C}^{\wedge} \mathrm{N}$ based unoccupied orbitals. It can be clearly seen that the broadened absorption, relative to $\mathbf{1 a}$, is well predicted by TDDFT. In this case all low-energy absorptions are associated with a MLCT transition associated with the terpyridine ligand, and transitions to the cyclometalated ligand are predicted to occur at increased energy. These results correlate well with the observations made during the $\mathrm{p} K_{\mathrm{a}}$ determination of $\mathbf{2} \mathbf{b}$. When changing the properties of the cyclometalated ligand, by protonation of the ester functionality, the most significant changes in the spectrum are expected at those wavelengths where this ligand is strongly involved in the transition. Indeed, the strongest optical changes upon protonation of the cyclometalated ligand in $\mathbf{2} \mathbf{b}$ occur around $350 \mathrm{~nm}$, Figure 3, exclusively where transitions associated with this ligand are predicted by theory.

The strong splitting of the three highest occupied molecular orbitals in $\left[\mathrm{Ru}\left(\mathrm{MeO}_{2} \mathrm{C}-\mathrm{C}^{\wedge} \mathrm{N}^{\wedge} \mathrm{N}\right)(\text { tpy })\right]^{+}, \mathbf{3} \mathbf{a}^{\prime}$, reflects both the asymmetry around the ruthenium atom and the strong ligand field resulting from the cyclometalated $\mathrm{MeO}_{2} \mathrm{C}-\mathrm{C}^{\wedge} \mathrm{N}^{\wedge} \mathrm{N}$ ligand. In contrast to the situation in $\mathbf{2 a}$, unoccupied molecular orbitals of low energy associated with the cyclometalated ligand are available. As a consequence, the visible absorption has a large component in which the electron density is increased on the cyclometalated ligand in the excited state. Again these results correlate to the observations made during the $\mathrm{p} K_{\mathrm{a}}$ determination, Figure 4. Protonation of the cyclometalated ligand in $\mathbf{3 b}$ results in strong optical changes around $540 \mathrm{~nm}$. A more thorough analysis of the electronic properties of these and related complexes can be found elsewhere. ${ }^{74}$

The weak performance of the $\mathbf{2} \mathbf{b}$-sensitized compared to the 3b-sensitized dye can be rationalized with the aid of these calculations. In the excited state, the electron in $\mathbf{2 b}$ is effectively located at the remote site of the terpyridine ligand. It has been found previously that such a state can result in a number of situations. The neutral complex $\left[\mathrm{Ru}(\mathrm{NCS})\left(\mathrm{HO}_{3} \mathrm{P}-\mathrm{ttpy}\right)(\mathrm{biq})\right]^{75}$ (ttpy is $4^{\prime}$-tolyl-2,2':6', $2^{\prime \prime}$-terpyridine, biq $=2,2^{\prime}$-biquinoline) is completely inactive when attached to $\mathrm{TiO}_{2}$, showing a peak

(74) Wadman, S. H.; Lutz, M.; Tooke, D. M.; Spek, A. L.; Frantiček, H.; Havenith, R. W. A.; Van Klink, G. P. M.; Van Koten, G. Consequences of $\mathrm{N}, \mathrm{C}, \mathrm{N}^{\prime}$ - and $\mathrm{C}, \mathrm{N}, \mathrm{N}^{\prime}$-coordination modes on electronic and photophysical properties of cyclometalated aryl ruthenium(II) complexes. Inorg. Chem. 2009, 48 (5), 1887-1900.

(75) Jing, B. W.; Zhang, H.; Zhang, M. H.; Lu, Z. H.; Shen, T. Ruthenium(II) thiocyanate complexes containing 4'-(4-phosphonatophenyl)-2,2': $6^{\prime}, 2^{\prime \prime}$-terpyridine: synthesis, photophysics and photosensitization to nanocrystalline $\mathrm{TiO}_{2}$ electrodes. J. Mater. Chem. 1998, 8 (9), 20552060.
IPCE of only $1.75 \%$. It was reasoned that this was a direct result of the excited state being localized on the remote biq ligand, as it has the lowest energy. ${ }^{39}$ However, $\left[\mathrm{Ru}(\mathrm{NCS})_{2}(\mathrm{dcbiqH})_{2}\right](\mathrm{TBA})_{2}$ (dcbiqH $\mathrm{H}_{2}=4,4^{\prime}$-dicarboxy-2,2'-biquinoline), which is attached to $\mathrm{TiO}_{2}$ by the funcionalized biq ligand, also reached a IPCE of only $3 \%$. This complex injected electrons from vibrationally hot states only, since the energy of the excited state located on the biq ligand is actually below the conduction band (CB) edge of $\mathrm{TiO}_{2}{ }^{43}$ When anchored to $\mathrm{SnO}_{2}$, with a CB edge approximately $0.5 \mathrm{~V}$ more positive, the complex displayed more efficient injection. Using TD-DFT calculations it was also demonstrated that the inefficient injection from trans- $\left[\mathrm{Ru}\left(\mathrm{NCS}_{2}\right)(\mathrm{L})\right](\mathrm{L}=$ quaterpyridine-based ligand) is a result of the decreased energy of the excited state in the complex. ${ }^{71}$

A second situation arises when the energy of the excited state possesses sufficient driving force to inject the electron into the $\mathrm{CB}$ of $\mathrm{TiO}_{2}$. DFT calculations showed that in the complex $\left[\mathrm{Ru}(\mathrm{NCS})_{2}\left(\mathrm{H}_{2} \mathrm{dcbpy}\right)(\mathrm{dppz})\right]\left(\mathrm{H}_{2} \mathrm{dcbpy}=4,4^{\prime}\right.$-dicarboxy-2,2'-

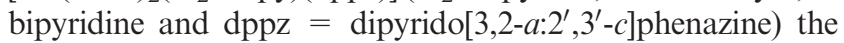
LUMO is localized on the dppz ligand and bpy-centered orbitals are available at only slightly higher energy. ${ }^{63}$ This complex reached a maximum IPCE of $54 \%$, and $5.3 \%$ overall efficiency in a DSSC, clearly showing efficient charge injection. It is likely that, due to the small energy difference, significant dcbpy-based character is mixed into the excited state, facilitating electron transfer from the dppz-based excited state.

In the case of $\mathbf{2} \mathbf{b}$ the lowest excited state is located on the terpyridine ligand and possesses sufficient driving force for electron injection. However, unlike the situation in $\left[\mathrm{Ru}(\mathrm{NCS})_{2^{-}}\right.$ $\left.\left(\mathrm{H}_{2} \mathrm{dcbpy}\right)(\mathrm{dppz})\right]$, the $\mathrm{N}, \mathrm{C}, \mathrm{N}^{\prime}$-binding ligand $\mathbf{6}$ does not possess states of appropriate energy, and electron injection is greatly retarded, resulting in the low IPCE value. This in contrast to $\mathbf{3 b}$, in which the additional electron density is largely located on the cyclometalated $\mathrm{C}^{\wedge} \mathrm{N}^{\wedge} \mathrm{N}$ ligand in the excited state, and efficient electron transfer can occur. In the case of $\mathbf{4 b}$ the additional carboxylate substituent further lowers the energy of the unoccupied levels. This would induce a larger component of the excited state to be associated with the cyclometalated $\mathrm{C}^{\wedge} \mathrm{N}^{\wedge} \mathrm{N}$ ligand and an even more efficient electron injection. Each protonation step during the titration of $\mathbf{4} \mathbf{b}$ indeed results in significant changes in the visible electronic spectrum.

\section{Conclusion}

We have demonstrated that replacing a coordinative $\mathrm{Ru}-\mathrm{N}$ bond by a covalent carbon-to-ruthenium bond results in both a 
red shift and a broadening of the optical absorption of the corresponding ruthenium complex. In a series of complexes featuring the $\mathrm{N}, \mathrm{N}^{\prime}, \mathrm{N}^{\prime \prime}$-, $\mathrm{N}, \mathrm{C}, \mathrm{N}^{\prime}$-, and $\mathrm{C}, \mathrm{N}, \mathrm{N}^{\prime}$-binding modes, the visible absorption was both strongly bathochromic shifted and broadened upon cyclometalation. The complexes were prepared and analyzed in the ester-protected form and are photostable. Deprotection and grafting onto $\mathrm{TiO}_{2}$ resulted in a small additional red shift of the absorption features. The sensitizing properties of the $\mathrm{C}, \mathrm{N}, \mathrm{N}^{\prime}$-cyclometalated compounds $\mathbf{3 b}$ and, especially, $\mathbf{4} \mathbf{b}$ are superior to those of the noncyclometalated, $\mathbf{1 b}$. In a device using a $\gamma$-butyrolactone-based electrolyte, $\mathbf{4 b}$ is able to achieve short circuit currents comparable to the benchmark N719. In contrast, the N,C, $\mathbf{N}^{\prime}$-cyclometalated $\mathbf{2 b}$ reached only low IPCE values. The electronic absorption spectra of the complexes were calculated by TD-DFT to rationalize the experimental results. The optical assignment based on these calculations agreed with the spectral changes observed during $\mathrm{pH}$ titration. The poor performance of the $\mathbf{2} \mathbf{b}$-sensitized device is a result of an isolated excited state located on the remote terpyridine ligand, unable to efficiently inject the electron into the $\mathrm{TiO}_{2}$ conduction band.

The present results show that the red shift resulting from the introduction of a covalent carbon-to-ruthenium bond can be utilized as a tool to increase the red response of sensitizers for dye-sensitized solar cells, as long as care is taken that the nature of the excited state is appropriate for electron injection. The cyclometalated complexes are photostable in the ruthenium(II) as well as in the oxidized state.

\section{Experimental Section}

General Procedures. All air-sensitive reactions were performed under a dry nitrogen atmosphere using standard Schlenk techniques. Absolute solvents were dried over appropriate drying agents and distilled before use. All other solvents and reagents were purchased and used as received. ${ }^{1} \mathrm{H}$ and ${ }^{13} \mathrm{C}\left\{{ }^{1} \mathrm{H}\right\}$ NMR spectra were recorded at $298 \mathrm{~K}$ on a Varian $300 \mathrm{MHz}$ Inova spectrometer and on a Varian $400 \mathrm{MHz}$ NMR system. NMR spectra were referenced to the solvent residual signal. ${ }^{76}$ Spectral assignments were based on chemical shift and integral considerations as well as COSY and NOESY twodimensional experiments. Solution UV-vis spectra were recorded on a Cary 50 Scan UV-visible spectrophotometer, and solid-state UV-vis spectroscopy was performed on a Cary 5 UV-vis-NIR spectrophotometer operating in diffuse reflectance mode. Infrared spectra were recorded on a Perkin-Elmer Spectrum One FT-IR spectrometer. Cyclic voltammograms were recorded in a single-compartment cell under a dry nitrogen atmosphere. The cell was equipped with a Pt microdisk working electrode, a Pt wire auxiliary electrode, and a $\mathrm{Ag} / \mathrm{AgCl}$ wire pseudoreference electrode. The working electrode was polished with alumina nano powder between scans. All redox potentials are reported against the ferrocene-ferrocenium $\left(\mathrm{Fc} / \mathrm{Fc}^{+}\right)$redox couple used as an internal standard. ${ }^{64,77}$ Potential control was achieved with a PAR model 263A potentiostat. All electrochemical samples were $10^{-1} \mathrm{M}$ in $\mathrm{Bu}_{4} \mathrm{NPF}_{6}$ as the supporting electrolyte in $\mathrm{CH}_{3} \mathrm{CN}$ distilled over $\mathrm{KMnO}_{4}$ and $\mathrm{Na}_{2} \mathrm{CO}_{3}$. MS measurements were carried out on an Applied Biosystems Voyager DE-STR MALDI-TOF MS. Elemental analyses were carried out by Kolbe Mikroanalytisches Laboratorium

(76) Gottlieb, H. E.; Kotlyar, V.; Nudelman, A. NMR chemical shifts of common laboratory solvents as trace impurities. J. Org. Chem. 1997, $62(21), 7512-7515$.

(77) Pavlishchuk, V. V.; Addison, A. W. Conversion constants for redox potentials measured versus different reference electrodes in acetonitrile solutions at 25 degrees C. Inorg. Chim. Acta 2000, 298 (1), $97-102$.
(Mülheim an der Ruhr, Germany). Compounds 5, 6, and $\mathbf{7}$ are prepared by modified literature procedure; see Supporting Information.

Photovoltaic Measurements. For the photovoltaic measurements, DSSCs were produced on masterplates, according to literature procedures. ${ }^{78}$ A masterplate consisted of two $\mathrm{SnO}_{2}$ : F-coated glass plates $(7.5 \times 10 \mathrm{~cm}$, LOF tec 8$)$, one of which contained five platinum counter-electrodes. The other glass plate contained five electrically isolated anatase $\mathrm{TiO}_{2}$ photoelectrodes $\left(4 \mathrm{~cm}^{2}\right)$ deposited by screen printing. $\mathrm{TiO}_{2}$ particles with a size of $\sim 30 \mathrm{~nm}$ were prepared following standard procedures. The colloidal particles were transferred from an aqueous suspension into a mixture of terpineol and ethyl cellulose to prepare a screen-printable paste. The active layers were dried and fired at 570 and $450{ }^{\circ} \mathrm{C}$ for $\mathrm{TiO}_{2}$ and $\mathrm{Pt}$, respectively, to remove all organic components and to establish sufficient interparticle contacts between the $\mathrm{TiO}_{2}$ particles. A typical film thickness of $13 \mu \mathrm{m} \mathrm{TiO} 2$ was obtained after firing. The two glass plates comprising the photo- and counter-electrodes were laminated together using Surlyn as a hotmelt foil. All the dyes were adsorbed by staining the electrodes in a $1 \mathrm{mM}$ dye solution in $\mathrm{MeOH} / \mathrm{MeCN}(3: 1, \mathrm{v} / \mathrm{v})$. Lastly the electrolyte containing $0.5 \mathrm{M} \mathrm{LiI}$ and $0.05 \mathrm{M} \mathrm{I}_{2}$ in $\gamma$-butyrolactone was added. For the IPCE measurements a $1000 \mathrm{~W}$ xenon lamp (Osram XBO/HS OFR) was used as the light source in combination with small-band-pass filters (Schott, fwhm $=6-10 \mathrm{~nm}$ ) to generate monochromatic light. The monochromatic light was passed through a chopper wheel to create a small, modulated signal on top of a constant signal originating from 0.3 sun bias illumination. The resulting modulated current was analyzed by a lock-in amplifier.

TD-DFT Calculations. DFT calculations were performed at the DZ Dunning ${ }^{79,80}$ level of theory for carbon, nitrogen, oxygen, and hydrogen, and using the Stuttgart RSC 1997 ECP relativistic core potential $^{81}$ for ruthenium using the B3LYP functional. Geometries were optimized using the Gamess $\mathrm{UK}^{82}$ program package. Subsequent TD-DFT calculations were run on the optimized geometry at the same level of theory using the Gaussian ${ }^{83}$ version 03 program package. Isovalue plots of the frontier molecular orbitals were made using MOLDEN. ${ }^{84}$

(78) Spath, M.; Sommeling, P. M.; van Roosmalen, J. A. M.; Smit, H. J. P.; van der Burg, N. P. G.; Mahieu, D. R.; Bakker, N. J.; Kroon, J. M. Reproducible manufacturing of dye-sensitized solar cells on a semiautomated baseline. Prog. Photovoltaics 2003, 11 (3), 207-220.

(79) Dunning, T. H. J. Chem. Phys. 1970, 53 (7), 2823-2833.

(80) Dunning, T. H.; Hay, P. J., In Methods of Electronic Structure Theory; 1977.

(81) Andrae, D.; Haussermann, U.; Dolg, M.; Stoll, H.; Preuss, H. Energy-adjusted abinitio pseudopotentials for the 2nd and 3rd row transition-elements. Theor. Chim. Acta 1990, 77 (2), 123-141.

(82) Guest, M. F.; Bush, I. J.; Van Dam, H. J. J.; Sherwood, P.; Thomas, J. M. H.; Van Lenthe, J. H.; Havenith, R. W. A.; Kendrick, J. The GAMESS-UK electronic structure package: algorithms, developments and applications. Mol. Phys. 2005, 103 (6-8), 719-747.

(83) Frisch, M. J.; Trucks, G. W.; Schlegel, H. B.; Scuseria, G. E.; Robb, M. A.; Cheeseman, J. R.; Montgomery, J. A., Jr.; Vreven, T.; Kudin, K. N.; Burant, J. C.; Millam, J. M.; Iyengar, S. S.; Tomasi, J.; Barone, V.; Mennucci, B.; Cossi, M.; Scalmani, G.; Rega, N.; Petersson, G. A.; Nakatsuji, H.; Hada, M.; Ehara, M.; Toyota, K.; Fukuda, R.; Hasegawa, J.; Ishida, M.; Nakajima, T.; Honda, Y.; Kitao, O.; Nakai, H.; Klene, M.; Li, X.; Knox, J. E.; Hratchian, H. P.; Cross, J. B.; Bakken, V.; Adamo, C.; Jaramillo, J.; Gomperts, R.; Stratmann, R. E.; Yazyev, O.; Austin, A.; J.; Cammi, R.; Pomelli, C.; Ochterski, J. W.; Ayala, P. Y.; Morokuma, K.; Voth, G. A.; Salvador, P.; Dannenberg, J. J.; Zakrzewski, V. G.; Dapprich, S.; Daniels, A. D.; Strain, M. C.; Farkas, O.; Malick, D. K.; Rabuck, A. D.; Raghavachari, K.; Foresman, J. B.; Ortiz, J. V.; Cui, Q.; Baboul, A. G.; Clifford, S.; Cioslowski, J.; Stefanov, B. B.; Liu, G.; Liashenko, A.; Piskorz, P.; Komaromi, I.; Martin, R. L.; Fox, D. J.; Keith, T.; Al-Laham, M. A.; Peng, C. Y.; Nanayakkara, A.; Challacombe, M.; Gill, P. M. W.; Johnson, B.; Chen, W.; Wong, M. W.; Gonzalez, C.; Pople, J. A. Gaussian 03; Gaussian, Inc, 2004.

(84) Schaftenaar, G.; Noordik, J. H. Molden: a pre- and post-processing program for molecular and electronic structures. J. Comput.-Aided Mol. Des. 2000, 14 (2), 123-134. 
Syntheses. Methyl 2-Acetylisonicotinicacid (9). Methyl isonicotinate $(8.2 \mathrm{~g}, 59 \mathrm{mmol})$ and $\mathrm{FeSO}_{4} \cdot 7 \mathrm{H}_{2} \mathrm{O}$ were dissolved in $\mathrm{MeCN}(160 \mathrm{~mL})$. TFA $(5 \mathrm{~mL}, 65 \mathrm{mmol}), t$-BuOOH $(70 \%$, $16 \mathrm{~mL}, 117 \mathrm{mmol})$, and acetaldehyde $(10 \mathrm{~mL}, 178 \mathrm{mmol})$ were added, and the solution was heated under reflux for $3 \mathrm{~h}$, during which additional $10 \mathrm{~mL}$ batches of acetaldehyde were added after $0.5,1$, and $2 \mathrm{~h}$. After cooling to room temperature, the volatiles were removed in vacuo. The residue was taken up in aqueous $1 \mathrm{M} \mathrm{NaOH}(100 \mathrm{~mL})$ and extracted with ethyl acetate $(4 \times 100 \mathrm{~mL})$. The product was purified by flash column chromatography on $\mathrm{SiO}_{2}$ (pentane/diethyl ether, 1:1), yielding 9 as a white solid $(7.0 \mathrm{~g}, 66 \%) .{ }^{1} \mathrm{H}$ NMR $\left(300 \mathrm{MHz}, \mathrm{CDCl}_{3}\right): \delta$ $8.70\left(\mathrm{~d},{ }^{3} J=6.4 \mathrm{~Hz}, 1 \mathrm{H}, \operatorname{Ar}^{6} H\right), 8.36\left(\mathrm{~s}, 1 \mathrm{H}, \operatorname{Ar}^{3} H\right), 7.88(\mathrm{~d}$, $\left.{ }^{3} J=6.4 \mathrm{~Hz}, 1 \mathrm{H}, \mathrm{Ar}^{5} \mathrm{H}\right), 3.85\left(\mathrm{~s}, 3 \mathrm{H}, \mathrm{CO}_{2} \mathrm{CH}_{3}\right), 2.60(\mathrm{~s}, 3 \mathrm{H}$, $\left.\mathrm{C}(\mathrm{O}) \mathrm{CH}_{3}\right) .{ }^{13} \mathrm{C}$ NMR $\left(75 \mathrm{MHz}, \mathrm{CDCl}_{3}\right): \delta 199.1,165.0,154.5$, 149.9, 138.6, 126.1, 120.8, 52.9, 25.8 .

1-(2-(4-Methylcarboxyl)pyridinyl)carbonylpyridinium iodide (10). A mixture of 9 (3.0 g, $17 \mathrm{mmol}), \mathrm{I}_{2}$ (4.34 g, $\left.17 \mathrm{mmol}\right)$, and pyridine $(10.0 \mathrm{~mL}, 124 \mathrm{mmol})$ was placed in an oil bath preheated to $130{ }^{\circ} \mathrm{C}$. The mixture solidified after $8 \mathrm{~min}$, was heated for another minute, and allowed to cool to room temperature. The resulting solid was crushed, dissolved in aqueous $\mathrm{MeCN}$ (15:85), and preabsorbed on $\mathrm{SiO}_{2}$. The product was purified by column chromatography on $\mathrm{SiO}_{2}\left(\mathrm{MeCN} / \mathrm{H}_{2} \mathrm{O}\right.$, 85:15) and recrystallized from hot $\mathrm{MeOH}$, yielding $\mathbf{1 0}$ as a cream-colored solid (3.72 g, 58\%). ${ }^{1} \mathrm{H}$ NMR $(300 \mathrm{MHz}$, DMSO- $\left.d_{6}\right): \delta 9.08\left(\mathrm{~d},{ }^{3} J=4.8 \mathrm{~Hz}, 1 \mathrm{H}, \mathrm{Ar}^{6} H\right), 9.00\left(\mathrm{~d},{ }^{3} J=\right.$ $\left.6.0 \mathrm{~Hz}, 2 \mathrm{H}, \mathrm{Ar}^{2^{\prime}} H\right), 8.73\left(\mathrm{t},{ }^{3} J=7.8 \mathrm{~Hz}, 1 \mathrm{H}, \mathrm{Ar}^{4^{\prime}} H\right), 8.35(\mathrm{t}$, $\left.{ }^{4} J=1.8 \mathrm{~Hz}, 1 \mathrm{H}, \mathrm{Ar}^{3} H\right), 8.28\left(\mathrm{dd},{ }^{3} J=7.8 \mathrm{~Hz}, 2 \mathrm{H}, \mathrm{Ar}^{3^{3}} H\right), 8.23$ $\left(\mathrm{dd},{ }^{3} J=4.8 \mathrm{~Hz},{ }^{3} J=1.8 \mathrm{~Hz}, 1 \mathrm{H}, \mathrm{Ar}^{6} H\right), 6.52\left(\mathrm{~s}, 2 \mathrm{H}, \mathrm{CH}_{2}\right), 3.94$ $\left(\mathrm{s}, 3 \mathrm{H}, \mathrm{CO}_{2} \mathrm{CH}_{3}\right) \cdot{ }^{13} \mathrm{C} \mathrm{NMR}\left(75 \mathrm{MHz}, \mathrm{DMSO}-d_{6}\right): \delta 190.8$, 164.3, 151.5, 151.0, 146.4, 146.3, 138.7, 127.8, 127.4, 120.2, 66.6, 53.2. Anal. Calcd for $\mathrm{C}_{14} \mathrm{H}_{13} \mathrm{IN}_{2} \mathrm{O}_{3}$ : C, 43.77; $\mathrm{H}, 3.41 ; \mathrm{N}, 7.29$. Found: C, 43.62; H, 3.46; N, 7.24.

4,4'-Di(methoxycarbonyl)-6-phenyl-2,2'-bipyridine (8). A suspension of $\mathbf{1 0}$ (1.13 g, $3 \mathrm{mmol}), 3$-benzoylacrylic acid $(0.54 \mathrm{~g}$, $3 \mathrm{mmol})$, and $\mathrm{NH}_{4} \mathrm{OAc}(2.5 \mathrm{~g}, 32 \mathrm{mmol})$ in $\mathrm{MeOH}(30 \mathrm{~mL})$ was heated under reflux, open to air, for $16 \mathrm{~h}$. After addition of $\mathrm{H}_{2} \mathrm{O}$ $(30 \mathrm{~mL})$, the volume was reduced in vacuo to $25 \mathrm{~mL}$ and the precipitate collected by filtration. The solid was dried by azeotrope with toluene and suspended in absolute $\mathrm{MeOH}(80 \mathrm{~mL})$. $\mathrm{H}_{2} \mathrm{SO}_{4}(1.5 \mathrm{~mL})$ was added. The resulting mixture was heated under reflux for $20 \mathrm{~h}$, neutralized with solid $\mathrm{KOH}$, and concentrated in vacuo. The solid was taken up in $\mathrm{K}_{2} \mathrm{CO}_{3}$ solution $(\mathrm{pH}$ $=11)$ and extracted with DCM $(2 \times 50 \mathrm{~mL})$. The product was filtered over $\mathrm{SiO}_{2}$ using diethyl ether, yielding $8(0.64 \mathrm{~g}, 61 \%)$. ${ }^{1} \mathrm{H}$ NMR $\left(400 \mathrm{MHz}, \mathrm{CDCl}_{3}\right): \delta 9.14\left(\mathrm{~s}, 1 \mathrm{H}, \mathrm{Ar}^{3} \mathrm{H}\right), 8.91(\mathrm{~s}, 1 \mathrm{H}$, $\left.\operatorname{Ar}^{5} H\right), 8.87\left(\mathrm{~d},{ }^{3} J=7.2 \mathrm{~Hz}, 1 \mathrm{H}, \mathrm{Ar}^{5^{\prime}} H\right), 8.38\left(\mathrm{~s}, 1 \mathrm{H}, \mathrm{Ar}^{3^{\prime}} H\right)$, $8.23\left(\mathrm{~d},{ }^{3} J=8.8 \mathrm{~Hz}, 1 \mathrm{H}, \mathrm{Ar}^{{ }^{2 \prime}} H\right), 7.91\left(\mathrm{~d},{ }^{3} J=6.8 \mathrm{~Hz}, 1 \mathrm{H}\right.$, $\left.\mathrm{Ar}^{6^{\prime}} H\right), 7.7-7.6\left(\mathrm{~m}, 3 \mathrm{H}, \mathrm{Ar}^{3^{\prime \prime}} H+\mathrm{Ar}^{4^{\prime \prime}} H\right), 4.04(\mathrm{~s}, 3 \mathrm{H}$, $\left.\mathrm{CO}_{2} \mathrm{CH}_{3}\right), 4.03\left(\mathrm{~s}, 3 \mathrm{H}, \mathrm{CO}_{2} \mathrm{CH}_{3}\right) .{ }^{13} \mathrm{C} \mathrm{NMR}\left(100 \mathrm{MHz}, \mathrm{CDCl}_{3}\right)$ : $\delta$ 166.0, 165.9, 157.8, 156.9, 156.2, 150.1, 139.6, 138.7, 138.4, $129.8,129.1,127.3,123.4,120.9,120.1,119.0,53.0,52.9$. Anal. Calcd for $\mathrm{C}_{20} \mathrm{H}_{16} \mathrm{~N}_{2} \mathrm{O}_{4}$ : C, 68.96; H, 4.63; N, 8.04. Found: C, $68.88 ; \mathrm{H}, 4.66 ; \mathrm{N}, 7.95$.

$\left[\mathrm{RuCl}_{3}\left(\mathbf{4}^{\prime}\right.\right.$-ethoxycarbonyl-2,2': $\mathbf{6}^{\prime}, \mathbf{2}^{\prime \prime}$-terpyridine $\left.)\right](11)$. A solution of $\mathbf{5}(766 \mathrm{mg}, 2.51 \mathrm{mmol})$ and $\mathrm{RuCl}_{3} \cdot 3 \mathrm{H}_{2} \mathrm{O}(658 \mathrm{mg}, 2.51$ $\mathrm{mmol})$ in absolute $\mathrm{EtOH}(200 \mathrm{~mL})$ was heated under reflux for $2 \mathrm{~h}$. The solid was isolated by filtration, washed with EtOH $(4 \times$ $20 \mathrm{~mL})$ and diethyl ether $(4 \times 20 \mathrm{~mL})$, and dried under air, yielding the product as a brown solid (1.13 g, 88\%). IR (ATR): $v_{\max } 1728 \mathrm{~s}, 1421 \mathrm{~s}, 1247 \mathrm{~s}, 766 \mathrm{~s} \mathrm{~cm}^{-1}$. Anal. Calcd for $\mathrm{C}_{18} \mathrm{H}_{15} \mathrm{Cl}_{3} \mathrm{~N}_{3} \mathrm{O}_{2} \mathrm{Ru}$ : C, 42.16; $\mathrm{H}, 2.95 ; \mathrm{N}, 8.19$. Found: $\mathrm{C}$, $42.17 ; \mathrm{H}, 3.05 ; \mathrm{N}, 8.06$.

$\left[\operatorname{Ru}\left(4^{\prime}\right.\right.$-ethoxycarbonyl-2,2': $\mathbf{6}^{\prime}, 2^{\prime \prime}$-terpyridine $)\left(2,2^{\prime}: 6^{\prime}, 2^{\prime \prime}\right.$-terpyridine $\left.)]\left(\mathbf{P F}_{\mathbf{6}}\right)_{\mathbf{2}} \mathbf{( 1 \mathbf { a }}\right)$. A mixture of $\mathbf{1 1}(99 \mathrm{mg}, 0.19 \mathrm{mmol})$ and $\mathrm{AgBF}_{4}$ $(131 \mathrm{mg}, 0.67 \mathrm{mmol})$ was suspended in acetone $(30 \mathrm{~mL})$, heated, open to air, under reflux for $2 \mathrm{~h}$, cooled to room temperature, and filtered over Celite. After removal of the solvent in vacuo, the solid was taken up in EtOH $(40 \mathrm{~mL})$ and tpy $(48 \mathrm{mg}, 0.21 \mathrm{mmol})$ was added. The mixture was heated under reflux for $16 \mathrm{~h}$. After filtration over Celite, aqueous $\mathrm{KPF}_{6}$ was added. Upon concentration in vacuo the product precipitated and was collected by filtration. Purification by column chromatography on $\mathrm{SiO}_{2}$ $\left(\mathrm{MeCN} / 0.5 \mathrm{M} \mathrm{NaNO}_{3}(\mathrm{aq}), 9: 1\right)$ yielded the product $(123 \mathrm{mg}$, $66 \%$ ) as an orange solid. ${ }^{1} \mathrm{H}$ NMR $\left(400 \mathrm{MHz}, \mathrm{CD}_{3} \mathrm{CN}\right): \delta 9.23(\mathrm{~s}$, $2 \mathrm{H}, \mathrm{D} 3,5), 8.80\left(\mathrm{~d},{ }^{3} J=8.4 \mathrm{~Hz}, 2 \mathrm{H}, \mathrm{A} 3,5\right), 8.69\left(\mathrm{~d},{ }^{3} J=6.8 \mathrm{~Hz}\right.$, $2 \mathrm{H}, \mathrm{C} 3), 8.52\left(\mathrm{~d},{ }^{3} J=7.6 \mathrm{~Hz}, 2 \mathrm{H}, \mathrm{B} 3\right), 8.49\left(\mathrm{t},{ }^{3} J=8.4 \mathrm{~Hz}, 1 \mathrm{H}\right.$, A4), $7.98\left(\mathrm{dd},{ }^{3} J=6.8 \mathrm{~Hz},{ }^{3} \mathrm{~J}=7.2 \mathrm{~Hz}, 2 \mathrm{H}, \mathrm{C} 4\right), 7.94\left(\mathrm{dd},{ }^{3} J=7.6\right.$ $\left.\mathrm{Hz},{ }^{3} J=7.2 \mathrm{~Hz}, 2 \mathrm{H}, \mathrm{B} 4\right), 7.42\left(\mathrm{~d},{ }^{3} J=5.6 \mathrm{~Hz}, 2 \mathrm{H}, \mathrm{C} 6\right), 7.34(\mathrm{~d}$, $\left.{ }^{3} J=4.8 \mathrm{~Hz}, 2 \mathrm{H}, \mathrm{B} 6\right), 7.24\left(\mathrm{dd},{ }^{3} J=7.2 \mathrm{~Hz},{ }^{3} J=5.6 \mathrm{~Hz}, 2 \mathrm{H}, \mathrm{C} 5\right)$, $7.16\left(\mathrm{dd},{ }^{3} J=7.2 \mathrm{~Hz},{ }^{3} J=4.8 \mathrm{~Hz}, 2 \mathrm{H}, \mathrm{B} 5\right), 4.67\left(\mathrm{q},{ }^{3} J=7 \mathrm{~Hz}, 2 \mathrm{H}\right.$, $\left.\mathrm{CH}_{2} \mathrm{CH}_{3}\right), 1.60\left(\mathrm{t},{ }^{3} \mathrm{~J}=7 \mathrm{~Hz}, 3 \mathrm{H}, \mathrm{CH}_{2} \mathrm{CH}_{3}\right) .{ }^{13} \mathrm{CNMR}(100 \mathrm{MHz}$, $\left.\mathrm{CD}_{3} \mathrm{CN}\right): \delta 165.0,158.8,158.5,157.2,155.9,153.6,153.4,139.3$, 139.2, 137.7, 137.6, 128.9, 128.5, 125.9, 125.6, 124.9, 123.8, 63.9, 14.6. IR (ATR): $v_{\max } 1724 \mathrm{~s}, 1248 \mathrm{~s}, 826 \mathrm{vs}, 764 \mathrm{~s} \mathrm{~cm}^{-1}$. Anal. Calcd for $\mathrm{C}_{33} \mathrm{H}_{26} \mathrm{~F}_{12} \mathrm{~N}_{6} \mathrm{O}_{2} \mathrm{P}_{2} \mathrm{Ru}$ : C, 42.64; H, 2.82; N, 9.04. Found: $\mathrm{C}$, 42.69; H, 2.89; N, 8.88.

[Ru(4-methoxycarbonyl-2,6-bis(2-pyridyl)phenyl)(2,2' :6', $\mathbf{2}^{\prime \prime}$-terpyridine $)]\left(\mathbf{P F}_{\mathbf{6}}\right)(\mathbf{2 a})$. A mixture of $\left[\mathrm{RuCl}_{3}(\mathrm{tpy})\right]^{85}(100 \mathrm{mg}, 0.23$ $\mathrm{mmol})$ and $\mathrm{AgBF}_{4}(145 \mathrm{mg}, 0.74 \mathrm{mmol})$ was suspended in acetone $(20 \mathrm{~mL})$, heated, open to air, to reflux for $2 \mathrm{~h}$, cooled to room temperature, and filtered over Celite. After removal of the solvent in vacuo, the solid was taken up in $n-\mathrm{BuOH}(30 \mathrm{~mL})$ and $6(70 \mathrm{mg}$, $0.24 \mathrm{mmol}$ ) was added. The mixture was heated under reflux for $16 \mathrm{~h}$. After filtration over Celite, aqueous $\mathrm{KPF}_{6}$ was added. Upon concentration in vacuo the product precipitated and was collected by filtration. Purification by column chromatography on $\mathrm{SiO}_{2}$ $\left(\mathrm{MeCN} / 0.5 \mathrm{M} \mathrm{NaNO}_{3}(\mathrm{aq}), 9: 1\right)$ yielded the product (119 mg, $64 \%)$ as a dark red solid. ${ }^{1} \mathrm{H}$ NMR $\left(400 \mathrm{MHz}, \mathrm{CD}_{3} \mathrm{CN}\right): \delta 8.87(\mathrm{~s}$, $2 \mathrm{H}, \mathrm{D} 3,5), 8.77\left(\mathrm{~d},{ }^{3} \mathrm{~J}=8 \mathrm{~Hz}, 2 \mathrm{H}, \mathrm{A} 3,5\right), 8.44\left(\mathrm{~d},{ }^{3} \mathrm{~J}=8 \mathrm{~Hz}, 2 \mathrm{H}\right.$, B3), $8.32\left(\mathrm{t},{ }^{3} \mathrm{~J}=8 \mathrm{~Hz}, 1 \mathrm{H}, \mathrm{A} 4\right), 8.27$ (d, $\left.{ }^{3} \mathrm{~J}=8 \mathrm{~Hz}, 2 \mathrm{H}, \mathrm{C} 3\right), 7.70$ $\left(\mathrm{dd},{ }^{3} \mathrm{~J}=8 \mathrm{~Hz},{ }^{3} J=7.6 \mathrm{~Hz}, 2 \mathrm{H}, \mathrm{B} 4\right), 7.66\left(\mathrm{dd},{ }^{3} \mathrm{~J}=8 \mathrm{~Hz},{ }^{3} \mathrm{~J}=\right.$ $7.6 \mathrm{~Hz}, 2 \mathrm{H}, \mathrm{C} 4), 7.13\left(\mathrm{~d},{ }^{3} \mathrm{~J}=5.6 \mathrm{~Hz}, 2 \mathrm{H}, \mathrm{C} 6\right), 7.09\left(\mathrm{~d},{ }^{3} \mathrm{~J}=5.6 \mathrm{~Hz}\right.$, 2H, B6), $6.92\left(\mathrm{dd},{ }^{3} J=7.6 \mathrm{~Hz},{ }^{3} J=5.6 \mathrm{~Hz}, 2 \mathrm{H}, \mathrm{B} 5\right), 6.74(\mathrm{dd}$, $\left.{ }^{3} J=7.6 \mathrm{~Hz},{ }^{3} J=5.6 \mathrm{~Hz}, 2 \mathrm{H}, \mathrm{C} 5\right), 4.06\left(\mathrm{~s}, 3 \mathrm{H}, \mathrm{CH}_{3}\right) .{ }^{13} \mathrm{C} \mathrm{NMR}$ (100 MHz, $\left.\mathrm{CD}_{3} \mathrm{CN}\right): \delta 233.1,169.1,168.9,159.8,155.4,153.5$, $152.8,143.2,136.7,136.4,133.9,127.3,124.7,124.6,123.4,123.1$, 122.7, 120.9, 52.5. IR (ATR): $v_{\max } 1706 \mathrm{~s}, 1247 \mathrm{~s}, 832 \mathrm{vs}, 758 \mathrm{~s}$ $\mathrm{cm}^{-1}$. Anal. Calcd for $\mathrm{C}_{33} \mathrm{H}_{24} \mathrm{~F}_{6} \mathrm{~N}_{5} \mathrm{O}_{2} \mathrm{PRu}: \mathrm{C}, 51.57 ; \mathrm{H}, 3.15 ; \mathrm{N}$, 9.11. Found: C, 51.43; H, 3.06; N, 8.95.

$[\mathbf{R u}$ (4-ethoxycarbonyl-6-phenyl-2,2'-bipyridine $)\left(\mathbf{2}, \mathbf{2}^{\prime}: \mathbf{6}^{\prime}, \mathbf{2}^{\prime \prime}\right.$-terpyridine $)]\left(\mathbf{P F}_{\mathbf{6}}\right)$ (3a). A suspension of $\left[\mathrm{RuCl}_{3}(\mathrm{tpy})\right]^{85}(92 \mathrm{mg}, 0.21$ mmol), 7 (67 mg, $0.22 \mathrm{mmol})$, and $N$-methylmorpholine (10 drops) in EtOH $(60 \mathrm{~mL})$ was heated under reflux for $16 \mathrm{~h}$. Aqueous $\mathrm{KPF}_{6}$ was added, and upon concentration in vacuo, the product precipitated and was collected by filtration. The product was purified by column chromatography on $\mathrm{SiO}_{2}(\mathrm{MeCN} /$ $\left.0.5 \mathrm{M} \mathrm{NaNO}_{3}(\mathrm{aq}), 9: 1\right)$. After crystallization from $\mathrm{MeCN} /$ toluene and washing with diethyl ether the product was obtained as a dark purple solid $(86 \mathrm{mg}, 52 \%) .{ }^{1} \mathrm{H}$ NMR $(400 \mathrm{MHz}$, $\left.\mathrm{CD}_{3} \mathrm{CN}\right): \delta 8.88$ (s, 1H, D5), 8.70 (s, $\left.1 \mathrm{H}, \mathrm{D} 3\right), 8.64\left(\mathrm{~d},{ }^{3} \mathrm{~J}=8 \mathrm{~Hz}\right.$, $2 \mathrm{H}, \mathrm{A} 3,5), 8.61\left(\mathrm{~d},{ }^{3} \mathrm{~J}=8 \mathrm{~Hz}, 1 \mathrm{H}, \mathrm{C} 3\right), 8.42\left(\mathrm{~d},{ }^{3} \mathrm{~J}=7.6 \mathrm{~Hz}, 2 \mathrm{H}\right.$, B3), $8.13\left(\mathrm{t},{ }^{3} \mathrm{~J}=8 \mathrm{~Hz}, 1 \mathrm{H}, \mathrm{A} 4\right), 7.96\left(\mathrm{~d},{ }^{3} \mathrm{~J}=8 \mathrm{~Hz}, 1 \mathrm{H}, \mathrm{E} 3\right), 7.90$ $\left(\mathrm{dd},{ }^{3} J=8 \mathrm{~Hz},{ }^{3} J=7.6 \mathrm{~Hz}, 1 \mathrm{H}, \mathrm{C} 4\right), 7.61\left(\mathrm{dd},{ }^{3} J=8 \mathrm{~Hz},{ }^{3} J=\right.$ $6.4 \mathrm{~Hz}, 2 \mathrm{H}, \mathrm{B} 4), 7.54\left(\mathrm{~d},{ }^{3} J=5.6 \mathrm{~Hz}, 1 \mathrm{H}, \mathrm{C} 6\right), 7.38\left(\mathrm{~d},{ }^{3} J=\right.$ $5.6 \mathrm{~Hz}, 2 \mathrm{H}, \mathrm{B} 6), 7.13\left(\mathrm{dd},{ }^{3} J=7.6 \mathrm{~Hz},{ }^{3} J=5.6 \mathrm{~Hz}, 1 \mathrm{H}, \mathrm{C} 5\right)$, $7.01\left(\mathrm{dd},{ }^{3} J=6.4 \mathrm{~Hz}, 2 \mathrm{H}, \mathrm{B} 5\right), 6.80\left(\mathrm{dd},{ }^{3} J=7.6 \mathrm{~Hz},{ }^{3} J=\right.$ $6.4 \mathrm{~Hz}, 1 \mathrm{H}, \mathrm{E} 4), 6.59\left(\mathrm{dd},{ }^{3} J=7.6 \mathrm{~Hz},{ }^{3} J=6.4 \mathrm{~Hz}, 1 \mathrm{H}, \mathrm{E} 5\right)$, $5.81\left(\mathrm{~d},{ }^{3} J=7.6 \mathrm{~Hz}, 1 \mathrm{H}, \mathrm{E} 6\right), 4.62\left(\mathrm{q},{ }^{3} J=7.2 \mathrm{~Hz}, 2 \mathrm{H}\right.$, $\left.\mathrm{CH}_{2} \mathrm{CH}_{3}\right), 1.57\left(\mathrm{t},{ }^{3} \mathrm{~J}=7.2 \mathrm{~Hz}, 3 \mathrm{H}, \mathrm{CH}_{2} \mathrm{CH}_{3}\right) .{ }^{13} \mathrm{C} \mathrm{NMR}(100$ $\left.\mathrm{MHz}, \mathrm{CD}_{3} \mathrm{CN}\right): \delta 184.6,166.0,165.5,157.7,156.9,155.6,153.8$, $151.8,151.6,147.1,138.4,136.2,135.9,135.7,130.5,130.0$, $127.3,126.9,125.9,124.5,124.0,123.0,122.5,118.9,117.8$, 63.2, 14.7. IR (ATR): $v_{\max } 1714 \mathrm{~s}, 1247 \mathrm{~s}, 833 \mathrm{vs}, 756 \mathrm{~s} \mathrm{~cm}^{-1}$.

(85) Sullivan, B. P.; Calvert, J. M.; Meyer, T. J. Cis-trans isomerism in (trpy) $\left(\mathrm{PPh}_{3}\right) \mathrm{RuCl}_{2}$. Comparisons between the chemical and physical properties of a cis-trans isomeric pair. Inorg. Chem. 1980, 19 (5), 1404-7. 
Anal. Calcd for $\mathrm{C}_{34} \mathrm{H}_{26} \mathrm{~F}_{6} \mathrm{~N}_{5} \mathrm{O}_{2} \mathrm{PRu}$ : C, 52.18; H, 3.35; N, 8.95. Found: C, 52.04; H, 3.30; N, 8.98.

$\left[\mathbf{R u}\left(4,4^{\prime}\right.\right.$-di(methoxycarbonyl)-6-phenyl-2,2' -bipyridine $)\left(2,2^{\prime}: 6^{\prime}, 2^{\prime \prime}\right.$ terpyridine $)]\left(\mathbf{P F}_{\mathbf{6}}\right)$ (4a). A suspension of $\left[\mathrm{RuCl}_{3}(\mathrm{tpy})\right]^{85}$ (127 mg, $0.29 \mathrm{mmol}), 8(102 \mathrm{mg}, 0.29 \mathrm{mmol})$, and $N$-methylmorpholine (10 drops) in $\mathrm{MeOH}(40 \mathrm{~mL})$ was heated under reflux for $4 \mathrm{~h}$. After cooling to room temperature, the solution was filtered. An aqueous solution of $\mathrm{KPF}_{6}$ was added, and upon removal of the $\mathrm{MeOH}$, the product precipitated and was collected by filtration. The product was purified by column chromatography on $\mathrm{SiO}_{2}(\mathrm{MeCN} / 0.5 \mathrm{M}$ $\mathrm{NaNO}_{3}(\mathrm{aq}), 9: 1$ ), followed by column chromatography on $\mathrm{Al}_{2} \mathrm{O}_{3}$ $\left(\mathrm{CH}_{2} \mathrm{Cl}_{2} / \mathrm{MeCN}, 2: 1\right)$. The product was then isolated as a dark purple solid (76 mg, 32\%). ${ }^{1} \mathrm{H}$ NMR $400 \mathrm{MHz}, \mathrm{CD}_{3} \mathrm{CN}$ ): $\delta 9.01$ (s, 1H, C3), 9.00 (s, 1H, D3), $8.72(\mathrm{~s}, 1 \mathrm{H}, \mathrm{D} 5), 8.65\left(\mathrm{~d},{ }^{3} \mathrm{~J}=8.0 \mathrm{~Hz}\right.$, $2 \mathrm{H}, \mathrm{A} 3,5), 8.42\left(\mathrm{~d},{ }^{3} J=8.0 \mathrm{~Hz}, 2 \mathrm{H}, \mathrm{B} 3\right), 8.16\left(\mathrm{t},{ }^{3} J=8.0 \mathrm{~Hz}, 1 \mathrm{H}\right.$, A4), $7.96\left(\mathrm{~d},{ }^{3} J=8.0 \mathrm{~Hz}, 1 \mathrm{H}, \mathrm{E} 3\right), 7.77\left(\mathrm{dd},{ }^{3} J=8.0 \mathrm{~Hz},{ }^{3} J=\right.$ $7.2 \mathrm{~Hz}, 2 \mathrm{H}, \mathrm{B} 4), 7.71\left(\mathrm{~d},{ }^{3} \mathrm{~J}=5.6 \mathrm{~Hz}, 1 \mathrm{H}, \mathrm{C} 6\right), 7.56\left(\mathrm{~d},{ }^{3} \mathrm{~J}=5.6 \mathrm{~Hz}\right.$, $1 \mathrm{H}, \mathrm{C} 5), 7.34\left(\mathrm{~d},{ }^{3} J=5.6 \mathrm{~Hz}, 2 \mathrm{H}, \mathrm{B} 6\right), 7.01\left(\mathrm{dd},{ }^{3} J=7.2 \mathrm{~Hz},{ }^{3} \mathrm{~J}=\right.$ $5.6 \mathrm{~Hz}, 2 \mathrm{H}, \mathrm{B} 5), 6.82\left(\mathrm{dd},{ }^{3} \mathrm{~J}=8.0 \mathrm{~Hz},{ }^{3} \mathrm{~J}=7.2 \mathrm{~Hz}, 1 \mathrm{H}, \mathrm{E} 4\right), 6.61$ $\left(\mathrm{dd},{ }^{3} J=7.2 \mathrm{~Hz},{ }^{3} J=7.2 \mathrm{~Hz}, 1 \mathrm{H}, \mathrm{E} 5\right), 5.83\left(\mathrm{~d},{ }^{3} J=7.2 \mathrm{~Hz}, 1 \mathrm{H}\right.$, E6), 4.16 (s, 3H, $\left.\mathrm{CO}_{2} \mathrm{CH}_{3}\right), 3.92\left(\mathrm{~s}, 3 \mathrm{H}, \mathrm{CO}_{2} \mathrm{CH}_{3}\right) .{ }^{13} \mathrm{C} \mathrm{NMR}$ $\left(100 \mathrm{MHz}, \mathrm{CD}_{3} \mathrm{CN}\right): \delta$ 183.1, 165.7, 165.0, 164.4, 157.2, 157.0, 154.6, 153.0, 151.7, 151.1, 146.2, 138.2, 135.5, 135.2, 134.8, 130.4, $129.5,126.3,125.5,125.2,123.3,122.7,122.4,122.0,118.7,117.3$, $53.0(2 \times)$. IR (ATR): $v_{\max } 1722 \mathrm{~s}, 1255 \mathrm{~s}, 1239 \mathrm{~s}, 836 \mathrm{vs}, 760 \mathrm{~s} \mathrm{~cm}^{-1}$. Anal. Calcd for $\mathrm{C}_{35} \mathrm{H}_{26} \mathrm{~F}_{6} \mathrm{~N}_{5} \mathrm{O}_{4} \mathrm{PRu}$ : C, 50.85; H, 3.17; N, 8.47. Found: C, 50.74; H, 3.15; N, 8.27.

[Ru(4'-carboxyl-2,2' $: 6^{\prime}, 2^{\prime \prime}$-terpyridine $)\left(2,2^{\prime} ; 6^{\prime}, 2^{\prime \prime}\right.$-terpyridine $\left.)\right]$ (1b). To a solution of 1a in DMF $(12 \mathrm{~mL})$ were added $\mathrm{H}_{2} \mathrm{O}(4.8$ $\mathrm{mL})$ and triethylamine $(2.4 \mathrm{~mL})$. The resulting mixture was heated under reflux for $24 \mathrm{~h}$, after which all volatiles were removed in vacuo, yielding the product as an orange solid. ${ }^{1} \mathrm{H}$ NMR (400 MHz, DMSO- $\left.d_{6}\right): \delta 9.35$ (s, 2H, D3,5), $9.06\left(\mathrm{~d},{ }^{3} \mathrm{~J}=\right.$ $8.4 \mathrm{~Hz}, 2 \mathrm{H}, \mathrm{A} 3,5), 8.96\left(\mathrm{~d},{ }^{3} J=8.0 \mathrm{~Hz}, 2 \mathrm{H}, \mathrm{C} 3\right), 8.79\left(\mathrm{~d},{ }^{3} J=\right.$ $8.4 \mathrm{~Hz}, 2 \mathrm{H}, \mathrm{B} 3), 8.52\left(\mathrm{t},{ }^{3} \mathrm{~J}=8.4 \mathrm{~Hz}, 1 \mathrm{H}, \mathrm{A} 4\right), 7.9-8.0(\mathrm{~m}, 4 \mathrm{H}$, $\mathrm{C} 4+\mathrm{B} 4), 7.45\left(\mathrm{~d},{ }^{3} \mathrm{~J}=5.2 \mathrm{~Hz}, 2 \mathrm{H}, \mathrm{C} 6\right), 7.41\left(\mathrm{~d},{ }^{3} J=5.2 \mathrm{~Hz}\right.$, 2H, B6), 7.2-7.3 (m, 4H, C5 + B5). MALDI-TOF-MS (DHB matrix): $m / z 568.06\left[\mathrm{M}^{+}-\mathrm{CO}_{2}\right]$ (calcd for $\mathrm{C}_{30} \mathrm{H}_{22} \mathrm{~N}_{6} \mathrm{Ru}$, 568.09), $612.07\left[\mathrm{M}^{+}\right]$(calcd for $\mathrm{C}_{31} \mathrm{H}_{22} \mathrm{~N}_{6} \mathrm{O}_{2} \mathrm{Ru}, 612.08$ ).

[Ru(4-carboxyl-2,6-di(2-pyridyl)phenyl) $\left(2,2^{\prime}: 6^{\prime}, 2^{\prime \prime}\right.$-terpyridine)] (2b). To a solution of $\mathbf{2 a}$ in DMF $(6 \mathrm{~mL})$ was added a solution of $\mathrm{NaOH}$ in $\mathrm{H}_{2} \mathrm{O}(4 \mathrm{M}, 2 \mathrm{~mL})$. The resulting solution was heated under reflux for $18 \mathrm{~h}$. After cooling to room temperature, acetic acid $(1 \mathrm{~mL})$ was added, and the mixture evaporated to dryness in vacuo. The product was washed with $\mathrm{H}_{2} \mathrm{O}$ and dried in vacuo, yielding the product as a dark red solid. ${ }^{1} \mathrm{H}$ NMR $(400 \mathrm{MHz}$, DMSO- $\left.d_{6}\right): \delta 9.04\left(\mathrm{~d},{ }^{3} J=8.0 \mathrm{~Hz}, 2 \mathrm{H}, \mathrm{A} 3,5\right), 8.85(\mathrm{~s}, 2 \mathrm{H}, \mathrm{D} 3,5)$, $8.71\left(\mathrm{~d},{ }^{3} \mathrm{~J}=7.6 \mathrm{~Hz}, 2 \mathrm{H}, \mathrm{B} 3\right), 8.35\left(\mathrm{t},{ }^{3} \mathrm{~J}=8.0 \mathrm{~Hz}, 1 \mathrm{H}, \mathrm{A} 4\right), 8.26(\mathrm{~d}$, $\left.{ }^{3} J=8.0 \mathrm{~Hz}, 2 \mathrm{H}, \mathrm{C} 3\right), 7.77\left(\mathrm{dd},{ }^{3} J=7.6 \mathrm{~Hz},{ }^{3} J=7.2 \mathrm{~Hz}, 2 \mathrm{H}, \mathrm{B} 4\right)$, $7.64\left(\mathrm{dd},{ }^{3} J=7.6 \mathrm{~Hz},{ }^{3} J=7.2 \mathrm{~Hz}, 2 \mathrm{H}, \mathrm{C} 4\right), 7.1-7.2(\mathrm{~m}, 4 \mathrm{H}, \mathrm{B} 6+$ B5), $6.96\left(\mathrm{~d},{ }^{3} J=5.2 \mathrm{~Hz}, 2 \mathrm{H}, \mathrm{C} 6\right), 6.72\left(\mathrm{dd},{ }^{3} J=7.2 \mathrm{~Hz},{ }^{3} J=5.2 \mathrm{~Hz}\right.$, 2H, C5). MALDI-TOF-MS (DHB matrix): $m / z \quad 610.08\left[\mathrm{M}^{+}\right]$ (calcd for $\mathrm{C}_{32} \mathrm{H}_{22} \mathrm{~N}_{5} \mathrm{O}_{2} \mathrm{Ru}, 610.08$ ).
[Ru(4-carboxyl-6-phenyl-2,2' -bipyridine $)\left(2,2^{\prime}: 6^{\prime}, 2^{\prime \prime}\right.$-terpyridine)] (3b). To a solution of 3a in DMF $(20 \mathrm{~mL})$ was added $\mathrm{H}_{2} \mathrm{O}(8 \mathrm{~mL})$ and triethylamine $(4 \mathrm{~mL})$. The resulting mixture was heated under reflux for $18 \mathrm{~h}$, after which all volatiles were removed in vacuo, yielding the product as a dark purple solid. ${ }^{1} \mathrm{H}$ NMR $400 \mathrm{MHz}$, DMSO- $\left.d_{6}\right): \delta 8.88$ (s, 1H, D3), $8.88\left(\mathrm{~d},{ }^{3} J=8.0 \mathrm{~Hz}, 2 \mathrm{H}, \mathrm{A} 3,5\right)$, $8.71\left(\mathrm{~d},{ }^{3} J=8.4 \mathrm{~Hz}, 1 \mathrm{H}, \mathrm{C} 3\right), 8.67\left(\mathrm{~d},{ }^{3} J=8.0 \mathrm{~Hz}, 2 \mathrm{H}, \mathrm{B} 3\right), 8.59$ (s, $1 \mathrm{H}, \mathrm{D} 5), 8.10\left(\mathrm{t},{ }^{3} J=8 \mathrm{~Hz}, 1 \mathrm{H}, \mathrm{A} 4\right), 7.87\left(\mathrm{dd},{ }^{3} J=8.4 \mathrm{~Hz},{ }^{3} J=\right.$ $7.2 \mathrm{~Hz}, 1 \mathrm{H}, \mathrm{C} 4), 7.7-7.8$ (m, 3H, E3 + B4), 7.3-7.4 (m, 3H, C6+ B6), $7.13\left(\mathrm{dd},{ }^{3} J=7.2 \mathrm{~Hz},{ }^{3} J=5.6 \mathrm{~Hz}, 2 \mathrm{H}, \mathrm{B} 5\right), 7.08\left(\mathrm{dd},{ }^{3} \mathrm{~J}=7.2\right.$ $\left.\mathrm{Hz},{ }^{3} J=5.6 \mathrm{~Hz}, 1 \mathrm{H}, \mathrm{C} 5\right), 6.65\left(\mathrm{dd},{ }^{3} J=8.0 \mathrm{~Hz},{ }^{3} J=7.2 \mathrm{~Hz}, 1 \mathrm{H}\right.$, E4), $6.41\left(\mathrm{dd},{ }^{3} J=7.2 \mathrm{~Hz},{ }^{3} J=7.2 \mathrm{~Hz}, 1 \mathrm{H}, \mathrm{E} 5\right), 5.52\left(\mathrm{~d},{ }^{3} J=7.2\right.$ $\mathrm{Hz}, 1 \mathrm{H}, \mathrm{E6}$ ). MALDI-TOF-MS (DHB matrix): $m / z 610.09\left[\mathrm{M}^{+}\right]$ (calcd for $\mathrm{C}_{32} \mathrm{H}_{22} \mathrm{~N}_{5} \mathrm{O}_{2} \mathrm{Ru}, 610.08$ ).

[Ru(4,4'-dicarboxyl-6-phenyl-2,2' -bipyridine) $\left(2,2^{\prime}: 6^{\prime}, 2^{\prime \prime}\right.$-terpyridine $\left.)\right]$ (4b). To a solution of $4 \mathbf{a}$ in DMF $(15 \mathrm{~mL})$ were added $\mathrm{H}_{2} \mathrm{O}(5 \mathrm{~mL})$ and triethylamine $(5 \mathrm{~mL})$. The resulting mixture was heated under reflux for $18 \mathrm{~h}$, after which all volatiles were removed in vacuo, yielding the product as a dark purple solid. ${ }^{1} \mathrm{H}$ NMR $(400 \mathrm{MHz}$, DMSO- $\left.d_{6}\right): \delta 9.10(\mathrm{~s}, 1 \mathrm{H}, \mathrm{C} 3), 9.09(\mathrm{~s}, 1 \mathrm{H}, \mathrm{D} 3), 8.93\left(\mathrm{~d},{ }^{3} J=\right.$ $8.0 \mathrm{~Hz}, 2 \mathrm{H}, \mathrm{A} 3,5), 8.70\left(\mathrm{~d},{ }^{3} \mathrm{~J}=8.0 \mathrm{~Hz}, 2 \mathrm{H}, \mathrm{B} 3\right), 8.68$ (s, 1H, D5), $8.21\left(\mathrm{t},{ }^{3} J=8.0 \mathrm{~Hz}, 1 \mathrm{H}, \mathrm{A} 4\right), 7.97\left(\mathrm{~d},{ }^{3} J=8.0 \mathrm{~Hz}, 1 \mathrm{H}, \mathrm{E} 3\right), 7.84$ $\left(\mathrm{dd},{ }^{3} J=8.0 \mathrm{~Hz},{ }^{3} J=7.6 \mathrm{~Hz}, 2 \mathrm{H}, \mathrm{B} 4\right), 7.71\left(\mathrm{~d},{ }^{3} J=5.6 \mathrm{~Hz}, 1 \mathrm{H}\right.$, C6), $7.55\left(\mathrm{~d},{ }^{3} J=5.6 \mathrm{~Hz}, 1 \mathrm{H}, \mathrm{C} 5\right), 7.32\left(\mathrm{~d},{ }^{3} J=6.0 \mathrm{~Hz}, 2 \mathrm{H}, \mathrm{B} 6\right)$, $7.10\left(\mathrm{dd},{ }^{3} J=7.6 \mathrm{~Hz},{ }^{3} J=6.0 \mathrm{~Hz}, 2 \mathrm{H}, \mathrm{B} 5\right), 6.73\left(\mathrm{dd},{ }^{3} J=8.0 \mathrm{~Hz}\right.$, $\left.{ }^{3} J=7.2 \mathrm{~Hz}, 1 \mathrm{H}, \mathrm{E} 4\right), 6.52\left(\mathrm{dd},{ }^{3} J=7.6 \mathrm{~Hz},{ }^{3} J=7.2 \mathrm{~Hz}, 1 \mathrm{H}, \mathrm{E} 5\right)$, $5.65\left(\mathrm{~d},{ }^{3} J=7.6 \mathrm{~Hz}, 1 \mathrm{H}, \mathrm{E} 6\right)$. MALDI-TOF-MS (DHB matrix): $m / z 654.07\left[\mathrm{M}^{+}\right]$(calcd for $\mathrm{C}_{33} \mathrm{H}_{22} \mathrm{~N}_{5} \mathrm{O}_{4} \mathrm{Ru}, 654.07$ ).

Acknowledgment. The authors gratefully acknowledge the support from the European Commission through the funding of the project FULLSPECTRUM within the Sixth Framework Program under number SES6-CT-2003-502620. Dr. S. Grecea-Tanase and Prof. J. Reedijk of the Leiden Institute of Chemistry are gratefully acknowledged for assistance with the CV measurements. The work of R.W.A.H. is part of the research program of the Stichting voor Fundamenteel Onderzoek der Materie (FOM), which is financially supported by the Nederlandse Organisatie voor Wetenschappelijk Onderzoek (NWO). We gratefully acknowledge $\mathrm{NWO} / \mathrm{NCF}$ for supercomputer time on ASTER, SARA (The Netherlands, project number SG-032).

Supporting Information Available: Complete author listing for ref 81 . Synthesis and characterization for ligands $\mathbf{5 , 6}$, and $\mathbf{7 .}$ $\mathrm{pH}$-dependent $\mathrm{UV}$ - vis spectra and $\mathrm{pH}$ dependence of extinction for $\mathbf{1 b}, \mathbf{2 b}, \mathbf{3 b}$, and $\mathbf{4 b}$. Optimized molecular geometries of $\mathbf{1} \mathbf{a}^{\prime}, \mathbf{2} \mathbf{a}$, and $\mathbf{3} \mathbf{a}^{\prime}$. Energies and isodensity plots of the frontier molecular orbitals in $\mathbf{1 a}^{\prime}, \mathbf{2} \mathbf{a}$, and $\mathbf{3} \mathbf{a}^{\prime}$. Complete listing of electronic transitions from TD-DFT. This material is available free of charge via the Internet at http://pubs.acs.org. 